Canadian Journal of Fisheries and Aquatic Sciences

Canadian Science Publishing

Journal canadien des sciences halieutiques et aquatiques

\title{
Juvenile Life-history Diversity and Population Stability of Spring Chinook Salmon in the Willamette River Basin, Oregon.
}

\begin{tabular}{|r|l|}
\hline Journal: & Canadian Journal of Fisheries and Aquatic Sciences \\
\hline Manuscript ID & cjfas-2015-0314.R2 \\
\hline Manuscript Type: & Article \\
\hline Complete List of Authors: & $\begin{array}{l}\text { Schroeder, R.; Oregon Department of Fish and Wildlife, Fish Research } \\
\text { Whitman, Luke; Oregon Department of Fish and Wildlife, Fish Research } \\
\text { Cannon, Brian; Oregon Department of Fish and Wildlife, Fish Research } \\
\text { Olmsted, Paul; Oregon Department of Fish and Wildlife, Fish Research }\end{array}$ \\
\hline Keyword: & $\begin{array}{l}\text { LIFE HISTORY < General, SALMON < Organisms, FRESHWATER < } \\
\text { Environment/Habitat, MIGRATION < General, POPULATION DYNAMICS < } \\
\text { General }\end{array}$ \\
\hline \multicolumn{2}{|c}{} \\
\hline
\end{tabular}

SCHOLARONE

Manuscripts 


\section{Juvenile Life-history Diversity and Population Stability of Spring Chinook Salmon in}

\section{2 the Willamette River Basin, Oregon.}

3

4 R. Kirk Schroeder ${ }^{1}$

5 Oregon Department of Fish and Wildlife, Corvallis Research Laboratory, 28655 Highway 34,

6 Corvallis, Oregon 97333, USA.

\section{Luke D. Whitman}

9 Oregon Department of Fish and Wildlife, Corvallis Research Laboratory, 28655 Highway 34,

10 Corvallis, Oregon 97333, USA, email: luke.whitman@oregonstate.edu

\section{Brian Cannon}

13 Oregon Department of Fish and Wildlife, Corvallis Research Laboratory, 28655 Highway 34,

14 Corvallis, Oregon 97333, USA, email: brian.cannon@oregonstate.edu

16 Paul Olmsted

17 Oregon Department of Fish and Wildlife, Corvallis Research Laboratory, 28655 Highway 34,

18 Corvallis, Oregon 97333, USA, email: paul.olmsted@oregonstate.edu

$21{ }^{1}$ Corresponding author (email: kirk.schroeder@oregonstate.edu) 
23 Abstract: Migratory and rearing pathways of juvenile spring Chinook salmon were

24 documented in the Willamette River basin to identify life histories and estimate their

25 contribution to smolt production and population stability. We identified six primary life

26 histories that included two phenotypes for early migratory tactics: fry that migrated up to

$27 \quad 140-200 \mathrm{~km}$ shortly after emergence (movers) and fish that reared for 8-16 months in natal

28 areas (stayers). Peak emigration of juvenile salmon from the Willamette River was in June-

29 July (subyearling smolts), March-May (yearling smolts), and November-December

30 (considered as "autumn smolts"). Alternative migratory behaviors of juvenile salmon were

31 associated with extensive use of diverse habitats that eventually encompassed up to $400 \mathrm{rkm}$

32 of the basin, including tributaries in natal areas and large rivers. Juvenile salmon that reared

33 in natal reaches and migrated as yearlings were the most prevalent life history and had the

34 lowest temporal variability. However, the total productivity of the basin was increased by the

35 contribution of fish with dispersive life histories, which represented over $50 \%$ of the total

36 smolt production. Life-history diversity reduced the variability in the total smolt population

37 by $35 \%$ over the weighted mean of individual life histories, providing evidence of a

38 considerable portfolio effect through the asynchronous contributions of life histories.

39 Protecting and restoring a diverse suite of connected habitats in the Willamette River basin

40 will promote the development and expression of juvenile life histories, thereby providing

41 stability and resilience to native salmon populations.

42

43 Keywords: portfolio effect, asynchrony, rearing, residence time, fry dispersal, movement 


\section{Introduction}

Diversity in Pacific salmon (Oncorhynchus spp.) is a result of its evolutionary history

46 in highly dynamic environments (Montgomery 2000; Waples et al. 2008) and confers species

47 and populations with a capacity to adapt in variable and uncertain environments (Healey and

48 Prince 1995; Waples et al. 2009). Life-history diversity, spatial structure, and differential

49 responses to environmental fluctuations can provide stability to regional populations and

50 stocks (Hilborn et al. 2003; Moore et al. 2010; Schindler et al. 2010). At the population level,

51 alternate juvenile life histories may contribute differently to adult salmon returns over time

52 and may buffer populations against environmental variability (Miller et al. 2010; Moore et al.

53 2014; Walsworth et al. 2014). Life-history strategies of Pacific salmon evolved to maximize

54 fitness in variable environments that occurred over broad geographic ranges of species

55 (Quinn et al. 2001; Waples et al. 2001; Brannon et al. 2004). Chinook salmon ( $O$.

56 tshawytscha) are widely distributed throughout the Pacific Northwest, occupy diverse

57 habitats that span coastal rivers to streams $>3000 \mathrm{~km}$ from the ocean, and display some of

58 the highest levels of diversity in life histories observed among all Pacific salmon (Healey

59 1991; Waples et al. 2001; Brannon et al. 2004). In addition to variable age at maturity, two

60 life-history strategies have been recognized; Chinook salmon that migrate to the ocean during

61 the first year of life as subyearlings and those that migrate as yearling smolts during their

62 second year of life (Taylor 1990; Healey 1991; Moran et al. 2013). Juvenile Chinook salmon

63 can also undertake long-distance movements prior to smolting (Bradford and Taylor 1997;

64 Connor et al. 2001; Shrimpton et al. 2014), resulting in multiple migratory and rearing

65 pathways that can contribute to diversity in life histories. Given the widely documented loss

66 of diversity within and among salmon populations that has occurred during the last century

67 (Gustafson et al. 2007; Waples et al. 2009) and the potential for continued and increased loss

68 in the near future from human-caused disturbances, it will be important to identify extant life- 
69 history diversity and its contribution to population dynamics for the development of effective

70 conservation and recovery measures (Ruckelshaus et al. 2002; Good et al. 2007).

71 Our study in the Willamette River basin, Oregon, was initiated to collect information

72 on the life histories of juvenile Chinook salmon for developing and planning conservation

73 and recovery measures for wild populations. Chinook salmon native to the Willamette River

74 basin return from the ocean as adults in late winter and early spring (spring run), the only

75 season when passage was historically possible at Willamette Falls. Early run timing and

76 isolation of the populations upstream of the falls resulted in a genetically divergent group

77 among Columbia River Chinook salmon (Waples et al. 2004; Narum et al. 2010; Matala et al.

78 2011). Populations of wild spring Chinook salmon in the upper Willamette River basin have

79 declined because of habitat degradation and simplification (e.g., dam construction and

80 development in floodplains), large hatchery programs, and size- or age-selective harvest

81 (Myers et al. 1998; Hulse et al. 2002). A key factor in the decline of wild salmon populations

82 was the construction in the 1950s and 1960s of large dams for flood control that blocked

83 access to $70-95 \%$ of the historic spawning areas for three populations of spring Chinook

84 salmon in the upper Willamette River basin and $25 \%$ of spawning habitat in the McKenzie

85 River subbasin where some headwater spawning areas remain accessible (ODFW and NMFS

86 2011). Data collected in the 1940s indicated considerable variation in migration timing, size,

87 and growth of wild juvenile salmon in the Willamette River, which included fry migrating

88 from natal areas shortly after emergence and the presence of subyearling and yearling smolts

89 (Craig and Townsend 1946; Mattson 1962). Diversity in life histories of juvenile Chinook

90 salmon may have been lost or may be constrained because of direct habitat loss, habitat

91 degradation, and decreases in the abundance of wild spawners. Populations of spring Chinook

92 salmon in the Willamette River basin were classified as an Evolutionarily Significant Unit

93 (ESU) and listed as threatened under the United States Endangered Species Act in 1999 
94 (NMFS 1999). A recovery plan was adopted in 2011 that identified actions including

95 conservation and restoration of riverine habitats, modification of discharge from dams, and

96 reintroduction of Chinook salmon upstream of dams (ODFW and NMFS 2011). Information

97 about the migratory and rearing behavior of juvenile salmon will be critical for planning and

98 implementing effective strategies. Previous studies on migration and rearing of juvenile

99 spring Chinook salmon have been geographically restricted to a single tributary (Zakel and

100 Reed 1984) or to the lower Willamette River (Friesen et al. 2007). Investigations have not

101 been conducted on migratory and rearing behavior of wild juvenile Chinook salmon

102 throughout the Willamette River basin or on the importance of diversity in salmon life

103 histories to population dynamics during the freshwater life stages.

104 The primary objectives of our study on spring Chinook salmon in the upper

105 Willamette River basin were to 1) identify the existing life-history diversity of wild juvenile

106 salmon, 2) identify general rearing areas for juvenile salmon in the basin, 3) estimate the

107 contribution of life histories to smolt production, and 4) estimate the effect of life-history

108 diversity on the stability of smolt numbers. Our results elucidate the importance of individual

109 migratory behaviors for smolt production, and will aid in the development of effective

110 conservation and recovery strategies for spring Chinook salmon in the Willamette River

111 basin. Our results will also add to the growing knowledge of diversity in life histories of

112 Chinook salmon within the Columbia River basin and elsewhere.

114 Methods

\section{Study area and populations}

116 The Willamette River basin (Fig. 1) is the fourth largest catchment of the Columbia

117 River and drains $29728 \mathrm{~km}^{2}$ (Baker et al. 2004). The basin encompasses diverse habitats and

118 land uses between the Cascade and Coast Range mountains, and joins with the Columbia 
119 River $163 \mathrm{~km}$ from the Pacific Ocean. The use of the Willamette River basin by anadromous

120 fish has been influenced by Willamette Falls located $43 \mathrm{~km}$ upstream from the confluence

121 with the Columbia River, which is formed by a $15 \mathrm{~m}$ high basalt ledge and was historically a

122 barrier to most anadromous fish species except for spring run Chinook salmon, winter run

123 steelhead (O. mykiss), and Pacific lamprey (Entosphenus tridentatus). Efforts to improve fish

124 passage at the falls began in the late 1800s with excavation of "steps" in the basalt, but

125 upstream passage remained difficult during late spring and summer until 1968-1975 when

126 concrete fishways were constructed along the side of the falls (NOAA 1981).

127 Chinook salmon in the Willamette River Basin return from the ocean in late winter

128 and early spring and most migrate to spawning tributaries and hold through summer until

129 they spawn in late August-late October. The primary spawning tributaries for spring

130 Chinook salmon were historically the Clackamas, North and South Santiam, McKenzie, and

131 Middle Fork Willamette rivers (Fig. 1). Spring Chinook salmon do not spawn in streams that

132 flow east from the Coast Range Mountains because adult holding and spawning habitat is

133 limited by low flow and high water temperatures during summer and autumn (Dimick and

134 Merryfield 1945; Parkhurst et al. 1950; Willis et al. 1960). Genetic analyses of spring

135 Chinook salmon in the Willamette River basin suggested weak but significant genetic

136 structuring among subbasins (Johnson and Friesen 2014); therefore juvenile fish sampled in

137 this study represented several populations within the upper Willamette River ESU.

138 We studied the migratory and rearing behavior of juvenile Chinook salmon that were

139 the progeny of adults spawning downstream of flood control dams or in accessible areas of

140 the McKenzie River subbasin (hereafter "wild”). The McKenzie River population was a

141 primary focus of this study because it produces a majority of the wild fish in the upper

142 Willamette River basin and the McKenzie subbasin is the only one with accessible headwater

143 spawning. The technical recovery team for the upper Willamette ESU designated Chinook 
144 salmon in the McKenzie River as a core population because of its historic abundance

145 (McElhany et al. 2003). The team also recognized the importance of life-history strategies to

146 population viability. We therefore propose that migratory behaviors of the McKenzie

147 Chinook salmon can provide a model of life-history diversity from which existing diversity in 148 other populations can be evaluated and recovery strategies can be developed.

150 Juvenile fish collection and tagging

151 We organized our study around two migrant types of juvenile Chinook salmon based 152 on the results of a study in the McKenzie River (Zakel and Reed 1984) that identified a large 153 migration of fry shortly after emergence (hereafter "movers") and migrations of fish that 154 remained in the spawning areas through at least their first summer of life ("stayers"). We 155 used a secondary classification for stayers based on their distinct seasonal migrations in 156 October-December (fall migrants) and mid-February-May (spring migrants). We captured 157 thousands of juvenile salmon throughout the Willamette River basin and used this data set to 158 identify migratory and rearing pathways and to estimate the contribution of life histories to smolt production. We tagged fish with passive integrated transponders (PIT) and installed tag

160 detection systems in existing fish bypass facilities to document passage. We sampled across

161 multiple brood years (year in which parents spawned) to encompass a range of intra- and 162 inter-annual variability in rearing and migratory conditions such as river discharge.

163 In 2005-2014, we captured movers with beach seines downstream of spawning areas 164 and stayers in a trap at Leaburg Dam as they migrated downstream after rearing in natal 165 areas. We supplemented our study of movers by capturing salmon fry from the 2011 and 1662012 brood years with seines within and downstream of natal areas to document dispersal 167 timing and distance. We also captured and tagged stayers within the natal reach of the 
168 McKenzie River subbasin in 2009-2014 to supplement information about the migration

169 timing of stayers from natal areas and their subsequent emigration from the Willamette River.

170 We sampled juvenile salmon within (Reach A) and downstream (Reach B) of

171 spawning areas, and in four reaches of the Willamette River (Fig 1). Primary spawning areas

172 in the North and South Santiam rivers are upstream of small diversion dams (rkm 25 and 32,

173 respectively), and downstream of spawning areas included $19 \mathrm{~km}$ of the Santiam River (Fig.

174 1). We used the 6-m high Leaburg Dam (rkm 55) as a break between primary (Reach A-1)

175 and secondary (Reach A-2) spawning reaches in the McKenzie River because about $85 \%$ of

176 the spawning occurred upstream of the dam (Sharpe et al. 2015). We sampled four reaches of

177 the Willamette River: Reach $\mathrm{C}=$ Coast Fork and Middle Fork Willamette rivers (rkm 301) to

178 McKenzie River (rkm 282), Reach D = McKenzie River to Santiam River (rkm 174), Reach

$179 \mathrm{E}=$ Santiam River to Willamette Falls (rkm 43), and Reach F = Willamette Falls to rkm 34

180 downstream of the Clackamas River (Fig. 1). Other areas sampled were Middle Fork

181 Willamette, Molalla, and Clackamas rivers to determine population sources of fry.

Movers

We documented the dispersal timing and distance of Chinook salmon fry (30-50 mm

185 FL) by capturing fish within and downstream of spawning areas. Fry from the 2011 and 1862012 brood years were captured with $6.1 \mathrm{~m}$ long x $1.8 \mathrm{~m}$ deep pole seines (3.2 $\mathrm{mm} \mathrm{mesh})$.

187 Our sampling coincided with emergence timing, which was estimated by accumulated

188 temperature units (ATU; sum of the daily mean temperature that exceeded $0^{\circ} \mathrm{C}$ ) using water

189 temperatures from U. S. Geological Survey gauges or temperature data loggers placed in

190 spawning reaches. We used spawning dates from redd surveys in each tributary to calculate

191 ATUs and we assessed emergence timing based on early spawning (first 5\% of redds) and

192 peak spawning. Fry emergence in the McKenzie River was estimated to be 1000 ATU in a 
193 previous study (Homolka and Downey 1995); therefore we began sampling at 850-900 ATU

194 (late November to early January) to document emergence. We seined in shallow water

195 habitats along the margin of the river channels or in side channels at 3-5 sites within each

196 reach, which were regularly sampled every 7-10 days. To sample across a range of flows,

197 we generally selected sites with a gradual slope and road access to the river but some sites

198 were accessed by boat. We compared the dates we first captured fry in tributaries to the

199 estimated dates of emergence for early and peak spawning. We then compared the dates fry

200 were first caught in tributaries to the mean dates fry were first captured in the Willamette

201 River. We assumed that salmon fry were widely distributed throughout the Willamette River

202 when they were captured at $\geq 75 \%$ of the sites. We estimated the distance fry dispersed as the

203 difference between the farthest downstream site we caught fry and the nearest spawning

204 location upstream. We assumed fry caught in the Willamette River were from the McKenzie

205 or Santiam subbasins and tested our assumption by comparing catch rates of fry (fry. set ${ }^{-1}$ )

206 among areas that included other potential population sources (Middle Fork Willamette,

207 Molalla, and Clackamas rivers).

208 Because fry were too small to tag when they dispersed, we sampled approximately

$209 \quad 20-125 \mathrm{~km}$ downstream of spawning areas in May-September 2005-2014 to capture and tag

210 juvenile salmon that were representative of the mover life history. We started sampling in

211 May (4-6 weeks after peak fry dispersal) to allow time for fry to reach tagging size and after

212 most yearling smolts would have migrated from the Willamette River. We tagged

213 subyearling Chinook salmon and differentiated subyearling and yearling fish by length;

214 yearlings comprised $<1 \%$ of the catch in the Willamette River and $0.1 \%$ of the catch in the

215 Santiam and McKenzie subbasins. We captured juvenile salmon by deploying a beach seine

216 (45.7 $\mathrm{m}$ long x $2.4 \mathrm{~m}$ deep ;c. 6-10 $\mathrm{mm}$ square mesh) away from shore and retrieving it in an

217 arc set (Hahn et al. 2007). Most sites were located on the inside bend of the main channel 
218 associated with submerged gravel bars, but we also sampled other habitats including side

219 channels. We sampled an average of 60 days per year among all rivers and reaches, with an 220 average annual sampling effort of 217 seine sets at 37 sites in the McKenzie River subbasin, 221256 seine sets at 58 sites in the Santiam River subbasin, and 390 seine sets at 58 sites in the

222 Willamette River. We generally sampled each reach every 7-10 days and revisited 2-5 sites 223 in each sampling cycle. Catch of subyearling salmon in Reach C of the Willamette River was 224 low (<3 fish $\cdot \mathrm{set}^{-1}$ v. $20 \mathrm{fish} \cdot \mathrm{set}^{-1}$ in Reach D or $28 \mathrm{fish} \cdot \mathrm{set}^{-1}$ in the McKenzie River),

225 therefore we excluded these data in our analyses of migration timing from the Willamette 226 River because of small sample sizes.

227 We counted and measured (FL, mm) all juvenile Chinook salmon and PIT-tagged fish $228 \geq 60-65 \mathrm{~mm}$ FL if they were not injured and the adipose fin was present. During our study, 229 all hatchery salmon released in the basin had an adipose fin clip to distinguish them from 230 wild fish. Captured fish were held in a live well with circulating river water, then transferred 231 to an anesthetic tub containing a buffered solution of tricaine methansesulfonate (MS-222, $\left.23260-80 \mathrm{mg} \cdot \mathrm{L}^{-1}\right)$. We injected the fish with $134.2 \mathrm{kHz}$ FDX-B PIT tags following 233 recommended tagging procedures (PTSC 2014) and released the fish at or near the capture 234 site after they had fully recovered.

Stayers

Our study of juvenile Chinook salmon rearing in natal areas focused on the McKenzie

238 population because headwater spawning habitats remain accessible and a fish bypass at

239 Leaburg Dam allowed us to tag fish as they migrated from natal areas or monitor the

240 migration of fish tagged upstream of the dam. We classified stayers by their migration

241 season: fall migrants in October-January or spring migrants in February-May. We captured

242 fish in the bypass flume at Leaburg Dam in 2005-2014 with a modified rotary screw trap (1.2 
$\mathrm{m}$ diameter) that funneled fish into a pipe attached to the live well and into an off-channel

244 raceway. Juvenile salmon were transferred into holding tanks with circulating water, and were handled and tagged by methods similar to those captured by beach seines. Fish were released into the bypass after they had fully recovered.

To collect additional information about the migration of fish from natal areas, we captured and tagged stayers in Reach A-1 of the McKenzie River subbasin in July-

September, 2009-2014. We started sampling in July when most fish began to reach tagging size and snorkeled throughout the reach to locate schools of fish. Two people positioned a pole seine ( $7 \mathrm{~m}$ long x $3.8 \mathrm{~m}$ deep with $3.2 \mathrm{~mm}$ mesh) downstream of the school and two snorkelers slowly crowded the fish toward the seine and helped pull the lead lines out of the water to trap fish in the bag. Captured fish remained submerged in the bag until they were transferred into a modified cooler with circulating stream water. Fish were handled and tagged in the same manner as fish captured by beach seines. After the fish had fully recovered, we released them at the location where they had been originally sighted.

\section{Tag detection and expansion factors}

We used detections of tagged fish to determine migration timing of juvenile Chinook salmon and identify migratory life histories. Tag detection systems were installed in the

261 juvenile fish bypasses at Leaburg Dam and Willamette Falls to continuously monitor the 262 migration of PIT-tagged juvenile Chinook salmon. We compared the migration timing of

263 tagged fish past Leaburg Dam to the seasonal catch of juvenile salmon at the bypass trap to assess if the fish we tagged upstream of the dam were representative of the migrant

265 population. We did not expand tag detections at Leaburg Dam because the mean flow was

266 similar between October-January $\left(136 \mathrm{~m}^{3} \cdot \mathrm{s}^{-1}\right)$ and February-May $\left(146 \mathrm{~m}^{3} \cdot \mathrm{s}^{-1}\right)$ and

267 subsequently was not a factor affecting the interpretation of seasonal migration. In contrast, 
268 the mean flow at Willamette Falls varied widely among seasons $\left(400-1100 \mathrm{~m}^{3} \cdot \mathrm{s}^{-1}\right)$, which

269 affected the entrainment and subsequent detection of tagged fish. Because we used

270 detections of tagged fish to estimate the relative abundance of migrants past Willamette Falls,

271 we expanded detections to account for the effect of flow and efficiencies of the bypass

272 system. Operation of the hydroelectric plant is run-of-river and the plant operates

273 continuously except for maintenance, construction, or extremely low river flow. A louver

274 rack in front of turbine intakes guided fish into bypass routes where PIT tag detectors were

275 located. We expanded tag detections at Willamette Falls by the efficiencies of PIT tag

276 antennas and fish guidance to the bypass, and by estimates of fish entrainment at different

277 flow levels. Entrainment was estimated by the proportion of the total flow diverted through

278 the plant and a measure of relative fish passage $\left(\mathrm{P}_{\mathrm{r}}\right)$ from controlled studies of tagged fish at

279 the falls to account for deviations from a 1:1 ratio between proportion of flow to the plant and

280 entrainment (see Appendix A for detail).

281

282 The daily number of tagged salmon past Willamette Falls was estimated with the equation:

$$
E T=\frac{T}{\left[(I / Q) \cdot P_{r} \cdot E_{G} \cdot E_{A}\right]}
$$

where $E T=$ expanded daily tag detection, $T=$ tags detected daily, $I=$ intake at hydroelectric

plant, $Q=$ discharge at Willamette Falls, $P_{r}=$ relative fish passage (ratio of entrained fish to discharge), $E_{G}=$ efficiency of fish guidance to bypass routes $(97 \%)$ and $E_{A}=$ efficiency of PIT tag antenna (90\%).

\section{Data analyses}

We defined life histories of juvenile Chinook salmon based on migratory and rearing

291 pathways of tagged fish. We used passage timing of juvenile salmon at the falls to define 
292 smolt types and estimated the residence time of juvenile salmon within and downstream of

293 natal areas to quantify the use of rearing areas within the basin. We considered the expanded

294 number of tagged juvenile salmon migrating past Willamette Falls to be an index of smolt

295 production and estimated the contribution of life histories to smolt production and population

296 stability. Subyearling and yearling smolts emigrated in spring and early summer of their first

297 or second year of life. Juvenile salmon that emigrated in fall and winter were considered to

298 be "autumn smolts" (e.g., Beckman and Dickhoff 1998), although many of these fish likely

299 overwintered in the Columbia River estuary and smolted the following spring.

Migration timing and rearing

We estimated passage timing at Willamette Falls from expanded detections of tagged

303 juvenile salmon and summarized detections by brood year to facilitate comparison among all

304 tag groups of different freshwater ages (i.e., tagged as subyearlings or yearlings). Detection

305 dates were converted to day of year using fraction of the year between the detection date and

306 the start of a year (January 1 of the year following spawning) and multiplying by 365 . Thus

307 for fish detected in their second year the fraction of the year was $>1.0$. We calculated the

308 median date of detection for each tag group and brood year from the frequency distribution of

309 expanded detections. Groups with $<25$ unexpanded tag detections were excluded.

310 To determine if juvenile salmon passing Willamette Falls continued to migrate, we

311 calculated migration rates of tagged fish to the Columbia River estuary using detection data

312 from a National Marine Fisheries Service study that sampled fish with a midchannel trawl

313 (Ledgerwood et al. 2004). We used rkm 75 (Jones Beach) as the detection point, which was

314 the approximate midpoint of the reach sampled by the trawl. We compared migration rates

$315\left(\mathrm{~km} \cdot \mathrm{d}^{-1}\right)$ of juvenile salmon to Willamette Falls and to the estuary for fish that were detected 
316 at both locations, and compared rates between subyearlings and yearlings from the McKenzie

317 population. We analyzed differences in median migration rates with a Kruskal-Wallis test.

318 We estimated the residence time of juvenile Chinook salmon from the McKenzie

319 River subbasin within or downstream of natal areas to quantify the use of rearing areas. For

320 movers captured downstream of natal reaches and stayers captured at Leaburg Dam,

321 residency was the number of days between release of tagged fish and subsequent detection at

322 Willamette Falls. Because movers spent time downstream of natal areas as fry prior to

323 tagging, we used the difference between tag date and date of peak fry catch in tributaries or

324 full occupancy in the Willamette River to account for additional rearing. For salmon tagged

325 in Reach A-1 of the McKenzie River, residency downstream of natal areas was the number of

326 days between detections at Leaburg Dam and Willamette Falls. We estimated the residence

327 time in natal areas for stayers as the number of days between the capture date at Leaburg

328 Dam and the mean estimated date of peak emergence in 2004-2014 (February 18).

329

$330 \quad$ Life-history diversity and stability

331 We defined life histories of juvenile salmon by migration timing from natal reaches

332 and passage at Willamette Falls, and estimated the relative abundance of smolt types from

333 expanded tag detections. Our analysis of migratory pathways was restricted to the McKenzie

334 River population because we could estimate migration from spawning areas for all juvenile

335 life stages. Therefore we used detections of fish tagged in the McKenzie and Willamette

336 (Reach D) rivers and summed the expanded number of detections for each of three seasons:

337 May-August of their first year of life, September-January, and February-May of their second

338 year of life. To account for differences in the number of tagged fish released among sampling

339 areas and years, we standardized the expanded number of detections per 1000 fish tagged. 
340 We estimated the relative percentage of stayers that migrated in fall or spring from the

341 seasonal catch at Leaburg Dam and detections at the dam of fish tagged upstream.

342 We analyzed the effect of life-history diversity on the stability of smolt production

343 over eight brood years using the standardized number of expanded detections at Willamette

344 Falls as an index of production. As a measure of population stability we calculated the

345 coefficient of variation $(\mathrm{CV})$ of the annual estimated smolt abundance at the falls for six

346 migratory life histories and the total indexed smolt population. Migratory life histories were

347 defined as the combination of migration from natal reaches and smolt type at Willamette

348 Falls: mover-subyearling smolt, mover-autumn smolt, mover-yearling smolt, stayer (fall

349 migrant)-autumn smolt, stayer (fall migrant)-yearling smolt, and stayer (spring migrant)-

350 yearling smolt. We used the weighted average CV of life histories (sum of the products of the

$351 \mathrm{CV}$ of life histories and their proportion) as an estimate of the predicted CV of smolt

352 production in the basin if the life histories were synchronous (Moore et al. 2014). We

353 compared the $\mathrm{CV}$ of each life history to the total $\mathrm{CV}$, and the predicted $\mathrm{CV}$ to that of the total

354 (or observed) CV as a measure of a portfolio effect whereby diversity increases stability

355 (Schindler et al. 2010; Moore et al. 2014). We assessed temporal correlation in the

356 standardized number of expanded detections by calculating the Pearson product-moment

357 correlation coefficients based on all pairwise comparisons among six migratory life histories

358 over eight brood years, and evaluated the degree of asynchrony in the population of juvenile

359 Chinook salmon migrating past Willamette Falls.

361 Results

362 We captured about 2300 fry in the McKenzie and Santiam subbasins and over 3700

363 fry in the Willamette River from the 2011 and 2012 brood years in December-April to

364 identify timing and dispersal distance of newly emerged fry (movers). After fish that had 
365 migrated as fry had reached sufficient size for tagging ( $>60-65 \mathrm{~mm}$ FL), we seined

366 downstream of spawning areas in spring and summer and tagged about 125000 juvenile

367 Chinook salmon (Table 1). We tagged juvenile Chinook salmon that remained in natal

368 reaches (stayers) either in Reach A-1 (8 741) or at Leaburg Dam in October-January (36 065)

369 and February-May (10 374) as they migrated downstream (Table 1).

Migration in Willamette Basin

372

Chinook salmon fry migrated from spawning areas of the Santiam and McKenzie

373

subbasins shortly after emergence and dispersed throughout the Willamette River within 4-6

weeks. We generally caught the first salmon fry in spawning tributaries near the predicted

375

time of emergence at 1000 ATUs for early spawners (Fig. 2). The mean date when fry were

caught in Reach D of the Willamette River was similar to the predicted date of emergence for

early spawners in the McKenzie River and first catch of fry in the lower McKenzie River

(Reach A-2 and B) indicating rapid dispersal (Fig. 2). In Reach E of the Willamette River, the mean date of first catch was similar to that in Reach D and was 25-33 days later than the dates of early emergence or first fry catch in the Santiam River subbasin. These data suggest that McKenzie fry continued to disperse downstream or Santiam fry did not migrate to the Willamette River until more fish had emerged in the North and South Santiam rivers. Catch of fry in the Willamette River was about four weeks later downstream of the falls (Reach F) than upstream, and fry were widely distributed in the Willamette River by mid-February (Fig.

2). Results from the 2012 brood year were similar, although catch of fry in the tributaries was generally later than the 2011 brood year, likely because our sampling effectiveness was reduced by high flows in December that were two to six times higher in 2012 than 2011. 
390 from spawning areas. To estimate dispersal distance, we assumed that most of the fry caught

391 in the Willamette River were from the McKenzie or Santiam populations. The McKenzie

392 River subbasin was the likely source of fry caught in Reach D of the Willamette River

393 because the catch rate in Reach C and the Middle Fork Willamette River was much lower

$394\left(0.9\right.$ fry $\left.\cdot \mathrm{set}^{-1}\right)$ than in the McKenzie River (3.4 fry $\cdot \mathrm{set}^{-1}$, Reach B) or the Willamette River

395 (4.6 fry $\cdot \mathrm{set}^{-1}$, Reach D). We caught no Chinook salmon fry in the Molalla River indicating

396 this spawning tributary was not a source for fry captured in Reach E of the Willamette River.

397 The catch rate of fry in the lower Clackamas River $\left(0.3\right.$ fry $\left.\cdot \operatorname{set}^{-1}\right)$ was much smaller than in

398 the Willamette River downstream of the Clackamas (3.1 fry $\left.\cdot \operatorname{set}^{-1}\right)$, indicating most fry caught

399 downstream of Willamette Falls originated from the Santiam or McKenzie subbasins.

$400 \quad$ Fry migrants that were tagged as subyearlings downstream of spawning areas

401 exhibited a diversity of migration timing past Willamette Falls. Juvenile salmon tagged in the

402 Willamette and Santiam rivers emigrated primarily as subyearlings (mean $=90.1$ and $99.8 \%$,

403 respectively), and median dates of emigration were late May to mid-July (Fig. 3). Median

404 dates of emigration for juvenile Chinook salmon tagged in the spawning tributaries (North

405 Santiam, South Santiam, and McKenzie rivers) were more protracted than fish tagged in the

406 Willamette and Santiam rivers (Fig. 3), and a higher percentage of the fish migrated as

407 autumn or yearling smolts (mean $=34-50 \%)$.

408 Most of the juvenile Chinook salmon that remained in natal reaches through their first

409 summer migrated to downstream areas in fall-winter. Of the tagged fish that passed Leaburg

410 Dam, 72\% were detected in October-January, which was comparable to the migration timing

411 based on the catch rate at the dam (mean fall-winter catch $=77 \% ; \mathrm{SD}=7.6 \%$ ). The migration

412 of stayers from natal reaches extended from October to June but generally peaked in the six

413 weeks from November through mid-December (Fig. 4). 
Juvenile Chinook salmon that migrated from the McKenzie River subbasin as stayers

415 were detected at Willamette Falls in early spring for both fall and spring migrants (Fig. 3).

416 The mean of the median dates of passage at the falls for fall migrants was over seven weeks

417 earlier than that for spring migrants (March $6 v$. April 27) and median passage dates were more protracted for fall migrants (late January-early April) than spring migrants (late Marchearly May). Although some of the fall migrants continued past Willamette Falls as autumn smolts, their passage timing indicated many overwintered in the McKenzie and Willamette

421 rivers and migrated as yearling smolts the following spring. Because tagged juvenile salmon migrated from natal reaches of the McKenzie River primarily in fall-winter, their passage timing at Willamette Falls was similar to the fall migrants tagged at Leaburg Dam (Fig. 3).

throughout the year with seasonal peaks. Based on the biweekly catch of fish at Leaburg Dam, migration peaked in winter-spring (fry) and late fall (Fig. 4). Tagged juvenile salmon from the McKenzie population were detected at Willamette Falls every month over the course of this study (Fig. 4), although fish migrated in August and September in only a couple of years when flow was above average and water temperature was below average. A migration peak of subyearling smolts at Willamette Falls in early summer followed fry 431 dispersal from spawning areas of the McKenzie River, and a small peak of passage at the

432 falls in early winter followed the fall-winter migration in the McKenzie River (Fig. 4). In 433 contrast to the relatively small migration of yearlings in the McKenzie River, a larger 434 migration of yearling smolts was observed at Willamette Falls, which reflects the contribution of fish rearing downstream of natal areas until their second year of life. 
Juvenile Chinook salmon that we tagged in the Willamette River basin were detected

439 in the lower Columbia River estuary during spring and early summer indicating continued

440 and directed migration to the estuary of the spring and summer migrants. Of the juvenile

441 salmon detected at both Willamette Falls and in the estuary, fish migrated at a significantly

442 higher rate from the falls to the estuary than from release sites to the falls (Kruskal-Wallis $\mathrm{H}$

$443=53.15 ; \mathrm{P}<0.001)$, with a mean time of 5-6 days to travel $131 \mathrm{~km}$ from the falls to the

444 estuary site. The median migration rate from the falls to the estuary was over twice as fast as

445 that from release sites to the falls for subyearlings $\left(25.2 v .11 .7 \mathrm{~km} \cdot \mathrm{d}^{-1}\right)$ and was over nine

446 times as fast to the estuary than to the falls for yearlings $\left(31.1 v .4 .6 \mathrm{~km} \cdot \mathrm{d}^{-1}\right)$.

\section{$448 \quad$ Rearing}

449 We estimated the residence time of juvenile Chinook salmon within or downstream of 450 natal areas to evaluate the relative importance of rearing areas. The mean residence time 451 downstream of natal areas for juvenile salmon of the mover life history was 125 days if they 452 emigrated as subyearling smolts (the predominant life history for movers), and was three times longer for those that emigrated as yearling smolts (Table 2). We could not directly measure the residence time of fry migrants in natal areas but the range was likely a few days for the early migrants we caught downstream up to about a month based on the difference between peak emergence (February 18) and peak catch of fry at Leaburg Dam in mid-March. was 9-13 months (range $=8-16$ months) before migrating to areas downstream (Table 2). For those that emigrated from the Willamette River in the same season they migrated from natal areas, $11 \%$ of their residency may have been in downstream areas (Table 2). By

461 comparison, about $30 \%$ of the residence time for fall migrants was in downstream areas if 462 they emigrated from the Willamette River as yearling smolts. 
464 Life-history diversity and stability

465 We documented six primary life histories for McKenzie juvenile salmon based on

466 migration from natal areas (movers and stayers) and smolt type at Willamette Falls (Fig. 5).

467 Although over 70\% of movers from the McKenzie River subbasin migrated as subyearling

468 smolts (Fig. 5), we found that a higher percentage of movers tagged in Reach D of the

469 Willamette River (McKenzie-source fish) migrated as subyearling smolts (89\%) compared to

470 those tagged in the lower McKenzie River (56\%). The migration of stayers from natal areas

471 was primarily in fall and early winter, but the majority of these fish overwintered and

472 emigrated from the Willamette River as yearling smolts. We estimated that the yearling smolt

473 life history represented about $69 \%$ of the smolts at Willamette Falls compared to much

474 smaller contingents of subyearling and autumn smolts (Fig. 5). However, we found

475 substantial variation in the contribution of six life histories to the total smolt production as

476 measured by expanded detections of tagged fish at Willamette Falls (Table 3). For example,

477 three migratory life histories contributed to yearling smolts and the largest contributor

478 (stayers migrating in spring) varied from 31 to $72 \%$. Two additional migrant types at

479 Willamette Falls were fish that emigrated as fry and subyearlings that emigrated in late

480 summer or early autumn (Fig. 5). Other minor life histories included male parr that resided

481 and matured within the spawning areas (precocial), and fish that emigrated past Willamette

482 Falls after their second summer indicating the presence of a two-year smolt life history.

483 We found evidence that temporal asynchrony in smolt numbers among life histories

484 and stability of particular life histories conferred stability to the smolt population of Chinook

485 salmon. In pairwise comparisons of the temporal variation in the number of detections for six

486 life histories, 13 of 15 were not significant $(P>0.05)$ indicating substantial asynchrony

487 among the contribution of life histories to the indexed smolt production (Table 4). However, 
488 life histories that shared the same early migratory phenotype when tagged (i.e., movers and 489 stayers) were more correlated with each other than those with dissimilar phenotypes 490 suggesting asynchrony could be attributed to these phenotypic differences. Life histories 491 were widely variable in their relative stability within the indexed smolt production (Fig. 6).

492 The coefficient of variation was highest for movers that remained in the Willamette River 493 through their first summer, although their relative proportion in total smolt production was

494 low. Juvenile Chinook salmon migrating from natal reaches as yearlings were the most 495 prevalent life history and had the lowest $\mathrm{CV}$, thereby having the greatest influence on 496 stability in the total smolt population. Although this life history represented $47 \%$ of the 497 indexed smolt population, the cumulative contribution of other life histories increased the 498 stability of the indexed smolt production. As evidence of a portfolio effect, we found the CV 499 of the total population (0.34) was $35 \%$ lower than that of the predicted CV (0.52) calculated 500 from the weighted mean CV of the six life histories (Fig. 6).

\section{Discussion}

This study identified six primary life histories of juvenile Chinook salmon based on

504 migration from natal areas and rearing time in the basin before emigration past Willamette

505 Falls. We documented the importance of habitats downstream of natal areas to all life

506 histories, and the importance of life-history diversity to smolt production and stability. We

507 identified two phenotypes for early migratory tactics: fry that migrated shortly after

508 emergence from redds (movers) and fish that migrated after rearing 8-16 months in spawning

509 areas (stayers). Primary smolt life histories emigrating from the Willamette River included

510 subyearling smolts from the mover phenotype and yearling smolts composed of mover and

511 stayer phenotypes. Juvenile salmon emigrating in fall and early winter also contributed to 
512 smolt production and although some may have been autumn smolts (e.g., Beckman and

513 Dickhoff 1998) others likely migrated as yearling smolts from the Columbia River estuary.

\section{Life-history diversity and stability}

516 Studies have demonstrated that life-history diversity provides stability and resilience

517 to salmon populations and fisheries (Hilborn et al. 2003; Schindler et al. 2010; Moore et al.

518 2014), and that juvenile life histories can contribute differentially to adult salmon populations

519 (Miller et al. 2010; Copeland et al. 2014; Jones et al. 2014; Walsworth et al. 2014). Diverse

520 juvenile life histories within and among populations can allow fish to respond to varying

521 environmental conditions by following different migratory and rearing pathways ("response

522 diversity"; Elmqvist et al. 2003). Our study provides critical evidence that life-history

523 diversity at juvenile life stages can provide a portfolio effect and confer stability within a

524 population through variable contributions to smolt production. Copeland and Venditti (2009)

525 found that three migratory life histories of Chinook salmon contributed to smolt production,

526 but were unable to account for contributions from fry migrants that emigrated from the natal

527 river shortly after emergence. Thorson et al. (2014) found evidence that spatial variation

528 among populations buffered the temporal variability in the production of age-0 Chinook

529 salmon in natal streams. We found that six life histories of Chinook salmon contributed

530 differently to smolt production over eight brood years. For example, contribution of the

531 subyearling smolt life history to the estimated total was generally small (mean $=19 \%)$, but

532 was $30 \%$ or more in some years. Fry migrants that reared through the summer also

533 contributed to smolt production, sometimes representing over $50 \%$ of the fish emigrating

534 from the Willamette River in fall and winter. Although certain life histories are a minor

535 contributor to smolt production in some years, they may represent a critical component that

536 contributes to the productivity of populations. In addition, productivity of certain life 
537 histories may be underestimated if their survival is constrained by the prevailing conditions

538 of rearing and migratory habitats in the Willamette River basin or Columbia River estuary.

539 We found that the stability conferred to Chinook salmon at freshwater life stages

540 resulted from asynchrony among life histories and the stability of specific life histories,

541 similar to that reported for steelhead populations in British Columbia (Moore et al. 2014). In

542 our study, the temporal variation among all life histories was more correlated within the life

543 histories of the two migratory phenotypes (movers and stayers) than between them, indicating

544 a degree of asynchrony attributed to diversity in early migratory behaviors. Juvenile Chinook

545 salmon that reared in natal reaches and migrated as yearling smolts had the greatest influence

546 on the overall stability of the indexed smolt population because their contribution to the total

547 was high and their abundance was relatively stable $(\mathrm{CV}=0.33)$, compared to that of the

548 mover-subyearling smolt $(\mathrm{CV}=0.68)$. However, because life histories contributed

549 differently to smolt production over time, the combined contribution of all life histories

550 provided stability to the smolt population and decreased the overall variability by $35 \%$.

551 Variability in the abundance of a steelhead population in a relatively pristine watershed was

552 reduced by about $20 \%$ because of diverse life histories (Moore et al. 2014), which was

553 smaller than we observed. However, their study was based on returning adults and the effects

554 of ocean mortality could reduce the asynchrony we observed in juvenile life stages.

555 Because mortality can be high in the early life of salmonids (Healey 1991; Bradford

556 1995; Quinn 2005), the asynchrony we observed in juvenile Chinook salmon could be

557 attributed to differential survival between movers and stayers in their respective early rearing

558 habitats. For example, the upper McKenzie River subbasin provides a relatively stable

559 hydrologic and thermal environment for stayers because of its volcanic geology (Jefferson et

560 al. 2006; Tague et al. 2007), which probably contributed to the stability of fish rearing in

561 natal areas. In contrast, water temperature and flow were more variable in the Willamette 
562 River during the early rearing period of January-April than in the natal reaches $(P<0.001)$.

563 Therefore, the abundance of movers is likely to be more variable than that of stayers not only

564 because of differences in survival in early rearing environments but also because of

565 variability in the additional mortality experienced by dispersing fry.

566 Life-history diversity allows fish to exploit a full suite of environments and ecological

567 niches (Murphy et al. 1997; Kraus and Secor 2004; Jones et al. 2014) and diversity of

568 migratory behaviors such as dispersal of individuals can increase the productivity and

569 resilience of fish populations (Kerr et al. 2010; Anderson et al. 2013; Copeland et al. 2014;

570 Jones et al. 2014). Migration of juvenile Chinook salmon to rearing habitats downstream of

571 natal reaches represent habitat shifts that entail trade-offs between costs such as predation and

572 energetic demands, and benefits such as increased growth opportunities. Juvenile salmon

573 migrating to the Willamette River as fry in winter or as fall migrants starting in October

574 would be rearing in winter habitat that is generally more productive than natal reaches. Mean

575 water temperature is higher in the Willamette River than in the upper McKenzie River by 1-

$57633^{\circ} \mathrm{C}$ in November-February when fall migrants and fry would leave natal reaches and the

577 temperature differential increases to $2-5^{\circ} \mathrm{C}$ through the peak rearing period in spring and

578 early summer. High winter flow in the Willamette River also provides a diverse suite of

579 shallow water habitats for rearing including flooded gravel bars, seasonal channels, and

580 floodplains. Thus juvenile salmon can exploit the spatial and temporal heterogeneity of

581 habitats in the basin through alternative migratory behaviors, which can functionally increase

582 carrying capacity and productivity (Bottom et al. 2005; Ruff et al. 2011; Armstrong and

583 Schindler 2013). As a measure of increased productivity because of migratory diversity, the

584 mean contribution to smolt production of the dispersive life histories was $53 \%$.

585 We focused much of our tagging effort on fish that migrated as fry and reared

586 downstream because we knew the least about this early migratory phenotype. We assumed 
587 the subyearling Chinook salmon we tagged downstream of natal reaches were representative 588 of fry that migrated shortly after emergence. Although we documented continued migration 589 of fry past Willamette Falls, we believe many of the migrants took up residence in the lower 590 spawning tributaries and in the Willamette River. Because stream residence behavior may 591 take a number of days to develop (Reimers 1973) salmon fry could disperse far distances 592 downstream before they settle. Dispersal of fry from natal reaches peaked in March, 593 therefore recruitment from upstream areas was limited when we captured thousands of 594 subyearling salmon in May-July indicating widespread residency of fry after dispersing. 595 We found that the average contribution of subyearling smolts to the total smolt 596 production was relatively small but we restricted our analysis to known McKenzie-source fish because we could not track all life histories in other subbasins (e.g., fall migrants in 598 North and South Santiam rivers). Therefore, we likely underestimated the contribution of 599 subyearling smolts because we excluded fish tagged in Reach E of the Willamette River, 600 which was an unknown mix of Santiam and McKenzie populations, and these fish migrated 601 almost exclusively as subyearling smolts (99.8\%). The majority of fish tagged in the Santiam 602 River subbasin also migrated as subyearling smolts (73\%). These data indicate the 603 contribution of the subyearling life history to total smolt production in the Willamette River 604 basin is higher than we estimated based on the McKenzie population.

605 Although a small population of fall Chinook salmon is present in the upper

606 Willamette River basin, we attributed the migratory behavior of juvenile salmon in this study

607 to the spring run because they are more abundant with a greater spawning distribution than 608 the fall run salmon. Hatchery fall Chinook salmon were released upstream of Willamette 609 Falls in 1971-1996 and a small naturalized population returns each year (2002-2014 mean = 6101268 adults) to spawn in the lower Santiam River and limited areas downstream such as the 611 lower Molalla River. By comparison, the mean annual return of wild and hatchery spring 
612 Chinook salmon to the upper Willamette River basin was about 33300 adults in 2002-2014,

613 excluding fin-clipped fish that returned to hatcheries. Genetic analyses of juvenile salmon in

614 2002-2004 indicated most were spring run, including $67-100 \%$ of the fish sampled at tagging

615 sites in the Willamette and Santiam rivers and 97-100\% of emigrating juvenile salmon

616 sampled at Willamette Falls in April-June and September-October (Schroeder et al. 2005).

\section{Migration and Rearing}

619 The downstream migration from natal areas of juvenile Chinook salmon at various

620 life stages in our study (fry, fall migrants, spring migrants) was similar to that described in

621 other studies (Bjornn 1971; Murphy et al. 1997; Copeland and Venditti 2009; Daum and

622 Flannery 2011). Areas downstream of natal reaches provided essential rearing habitat for

623 juvenile salmon in the Willamette River basin, with mean residence times of 4-13 months for

624 movers and up to 4 months for stayers. We documented extensive use of large river habitats

625 for all life stages of juvenile Chinook salmon including winter rearing, similar to that

626 reported for the Fraser River in Canada (Levings and Lauzier 1991) and rivers in Idaho

627 (Copeland et al. 2014). In contrast, Shrimpton et al. (2014) found that juvenile Chinook and

628 coho salmon (O. kisutch) in British Columbia, Canada used large rivers primarily as

629 migration corridors based on otolith analysis of adult salmon.

630 We documented Chinook salmon fry migrating up to 140-200 km downstream from

631 the nearest spawning areas within three to six weeks of emergence, which are among the

632 longest migration distances reported for salmon fry. Studies in Canada reported dispersal of

633 fry up to $100 \mathrm{~km}$ (unpublished data cited in Bradford and Taylor 1997), and the capture of

634 juvenile Chinook salmon in nonnatal tributaries of the lower Fraser River suggested longer

635 migration distances (Murray and Rosenau 1989). Long-distance dispersal of fry (100+ km)

636 was inferred in a study of Chinook salmon in the Snake River (Idaho and Washington) based 
637 on the genetic identification of relatively small fish $(60 \mathrm{~mm})$ from distant upstream

638 watersheds (Connor et al. 2001). These studies along with our data on rapid, long-distance

639 dispersal from spawning areas indicate fry can actively migrate as postulated by Healey

640 (1991) rather than being passively swept downstream (Thomas et al. 1969; Irvine 1986).

641 Fry migrants and subyearling smolts were present in all populations we studied.

642 Adult salmon in several tributaries of the upper Willamette River basin spawn downstream of

643 barrier dams where water temperature is higher during incubation and a subyearling life

644 history may be favored in these environments because of early fry emergence. However, a

645 large fry migration was present in the McKenzie population where salmon have access to

646 headwater areas suggesting other factors influenced fry dispersal. Fry migrants and

647 subyearling smolts were reported in Willamette spring Chinook salmon prior to construction

648 of dams (Dimick and Merryfield 1945; Craig and Townsend 1946; Mattson 1962), indicating

649 this migratory pathway is a natural component of the populations that has persisted despite

650 widespread changes in habitat quantity and quality. Billman et al. (2014) found that body

651 morphology of juvenile salmon in the Willamette River basin was correlated with life-history

652 tactics expressed as migratory behavior, which suggested that fry dispersal was associated

653 with differentiation in morphology.

654 We hypothesize that fry dispersal and emigration as subyearling smolts would be

655 favored in the upper Willamette River basin because other salmon runs were absent and

656 extensive areas of habitat were available downstream of natal reaches. Fry migrants would

657 not be competing for food and space with juveniles of other species such as fall Chinook and

658 coho salmon because they were historically absent upstream of Willamette Falls. Productive

659 rearing habitat for dispersing fry would have been expansive in the historic Willamette River,

660 which was a complex of braided channels connected to broad floodplains and side channels

661 during frequent floods (Benner and Sedell 1997) and bordered by mature riparian forests that 
662 provided structure to the river (Sedell and Froggatt 1984; Gregory et al. 2002). Life histories

663 of juvenile Chinook salmon in coastal rivers include the use of estuaries as nursery habitat by

664 fry migrants prior to ocean entry as subyearlings (Reimers 1973; Healey 1991; Bottom et al.

665 2005). The Willamette River could function as an equivalent nursery area for fry migrants,

666 thus providing the environmental template for the development of a successful life-history

667 strategy whereby fry can attain the growth necessary to smolt as subyearlings.

668

669 Management implications

670 Large hatchery programs, age- or size-selective harvest, simplification or loss of

671 habitat, and climate change can directly or indirectly reduce the diversity of life histories that

672 results in a loss of stability and viability within and among populations (Moore et al. 2010;

673 Carlson and Satterthwaite 2011; Anderson et al. 2015). Diverse habitats and spatial and

674 temporal connectivity to habitats provides the ecological template that allows for local

675 adaptation and the development and sustainability of diverse life histories (Rogers and

676 Schindler 2008; Waples et al. 2009; Fraser et al. 2011; Schindler et al 2015). Habitat for

677 juvenile salmon in the Willamette River basin has been greatly reduced or simplified by

678 direct loss (e.g., impassable dams) and decreases in water quality and quantity (e.g., reduced

679 flooding and loss of connectivity). Measures to increase the diversity and connectivity of

680 habitats and maintain the processes that produce habitat heterogeneity could therefore

681 increase the expression of life histories, contribute to population productivity, and help

682 increase the response diversity of populations to environmental fluctuations caused by

683 anthropogenic disturbances such as habitat loss and climate change (Beechie et al. 2013;

684 Jones et al. 2014; Walsworth et al. 2014; Schindler et al. 2015).

685 Our results showing the extensive use of the watershed by life histories of juvenile

686 Chinook salmon and the varying contributions of life histories to smolt production illustrates 
687 the importance of integrating habitat conservation and restoration with the spatial and 688 temporal scales at which life histories are expressed (Kocik and Ferrei 1998; Baguette et al. 689 2013). Conserving and restoring habitats for diverse life histories in the Willamette River 690 basin should extend spatially from high elevation natal reaches to large river habitats and 691 should provide longitudinal and lateral connectivity at the temporal scales of the migratory 692 and rearing pathways (Beechie et al. 2010; Schindler et al. 2015). Conservation and recovery 693 actions should include measures to restore a diverse suite of connected habitats to provide 694 benefits for all life histories not just the most common ones observed under current 695 conditions (Watters et al. 2003; Jorgensen et al. 2013; Copeland et al. 2014). For example, a 696 larger number of juvenile salmon migrated in the fall than in the spring from natal reaches of 697 the McKenzie River subbasin, but contribution of fall migrants to the estimated smolt 698 production was about $40 \%$ lower than spring migrants suggesting high winter mortality.

699 Winter habitats could be lost or reduced because of anthropogenic changes to the Willamette 700 River that include reduced frequency and magnitude of floods, increased duration of bank 701 full flows, and reduced channel complexity (Hulse et al. 2002; Wallick et al. 2007) resulting 702 in loss of velocity refugia and connectivity to floodplains. Actions such as removing bank 703 revetments and altering dam operations to more closely match historic hydrologic conditions 704 could improve winter habitat and also help buffer populations against climate change

705 (Beechie et al. 2013). Measures to reconnect adult and juvenile salmon to historic spawning 706 and rearing areas upstream of dams would increase habitat diversity in the basin and could 707 include effective upstream and downstream passage past dams and reservoirs, altered dam 708 operations, or removal of dams.

709 Our results indicate life-history diversity provides population stability during

710 freshwater life stages. Additional stability and resilience to populations should be conferred 711 through adult life stages because of varying residence times in the ocean within a year class 
712 (e.g., Jones et al. 2014; Moore et al. 2014) and analyses are underway to identify and quantify

713 the contribution of life histories within and among Willamette River basin populations over

714 10-12 brood years. The diversity observed in Willamette spring Chinook salmon should

715 increase the likelihood that some individuals in the population will survive to reproduce

716 under changing environmental conditions by spreading risks (bet-hedging strategy) across

717 time and space (Stearns 1976). Maintaining this diversity and the habitats that support it will

718 be critical considering the existing anthropogenic effects on salmon habitat within the basin

719 such as impassable dams, the potential negative effects of future population growth in the

720 Willamette Valley, and other uncertainties such as climate change.

\section{Acknowledgements}

723 The authors thank R. Lindsay and K. Kenaston for their help in planning and

724 implementing this study. We thank S. Akins, D. Hewlett, M. Hogansen, D. Jones, L.

725 McLaughlin, F. Monzyk, and M. Walker for their important contributions to this work. We

726 gratefully acknowledge the contributions of numerous seasonal field staff in capturing and

727 tagging fish for this study. We thank J. Tenney and D. Marvin of Pacific States Marine

728 Fisheries Commission for their assistance in maintaining the detection system at Willamette

729 Falls, and S. Downing and G. Brooks of National Marine Fisheries Service for the installation

730 and maintenance of the detection systems in the McKenzie River. Our installation of PIT-tag

731 detection systems would not have been possible without the cooperation of Eugene Water

732 and Electric Board and Portland General Electric, and we thank T. Shibahara of PGE for his

733 contributions. We appreciate reviews by T. Friesen, M. Johnson, and two anonymous

734 reviewers for their constructive comments that greatly improved the manuscript. This

735 research was largely funded by the Sport Fish Restoration Fund of the U.S. Fish and Wildlife

736 Service and Oregon Department of Fish and Wildlife. 


\section{$738 \quad$ References}

739 Anderson, J. H., Pess, G. R., Kiffney, P. M., Bennett, T. R., Faulds, P. L., Atlas, W. I., and

740 Quinn, T. P. 2013. Dispersal and tributary immigration by juvenile coho salmon

741 contribute to spatial expansion during colonisation. Ecol. Freshw. Fish 22(1): 30-42.

742

Armstrong, J. B., and Schindler, D. E. 2013. Going with the flow: spatial distributions of

Anderson, S. C., Moore, J. W., McClure, M. M., Dulvy, N. K., and Cooper, A. B. 2015. Portfolio conservation of metapopulations under climate change. Ecol. Appl. 25(2): 559-572. doi:10.1890/14-0266.1. juvenile coho salmon track an annually shifting mosaic of water temperature.

Baguette, M., Blanchet, S., Legrand, D., Stevens, V. M., and Turlure, C. 2013. Individual Ecosystems 16(8): 1429-1411. doi: 10.1007/s10021-013-9693-9.

Baker, J. P., Hulse, D. W., Gregory, S. V., White, D., Van Sickle, J., Berger, P. A., Dole, D., and Schumaker, N. H. 2004. Alternative futures for the Willamette River basin, Oregon. Ecol. Appl. 14(2): 313-324. doi:10.1890/02-5011.

Beckman, B. R., and Dickhoff, W. W. 1998. Plasticity in smolting in spring chinook salmon: relation to growth and insulin-like growth factor-I. J Fish Biol. 53:808-826. doi: 10.1111/j.1095-8649.1998.tb01834.x.

Beechie, T. J., Sear, D. A., Olden, J. D., Pess, G. R., Buffington, J. M., Moir, H., Roni, P., and Pollock, M. M. 2010. Process-based principles for restoring river ecosystems. BioScience 60(3): 209-222. doi:10.1525/bio.2010.60.3.7. 
761 Beechie, T., Imaki, H., Greene, J., Wade, A., Wu, H., Pess, G., Roni, P., Kimball, J., 762 Stanford, J., Kiffney, P., and Mantua, N. 2013. Restoring salmon habitat for a 763 changing climate. River Res. Appl. 29(8): 939-960. doi:10.1002/rra.2590.

764 Benner, P. A., and Sedell, J. R. 1997. Upper Willamette River landscape: a historic

765

766

767

768

769

770

771

772

773

774

775

776

777

778

779

780

781

782

783

784 perspective. In River quality: dynamics and restoration. Edited by D. A. Dunnette and A. Laenen. CRC Press, Lewis Publishers, New York, NY. pp. 23-47.

Billman, E. J., Whitman, L. D., Schroeder, R. K., Sharpe, C. S., Noakes, D. L. G., and Schreck C. B. 2014. Body morphology predicts future downstream migration in wild juvenile Chinook salmon in the Willamette River, Oregon, USA. J. Fish Biol. 84(4): 1097-1110. doi:10.1111/jfb.12482.

Bjornn, T. C. 1971. Trout and salmon movements in two Idaho streams as related to temperature, food, stream flow, cover, and population density. Trans. Am. Fish. Soc. 100(3): 423-438. doi:10.1577/1548-8659(1971)100<423:TASMIT>2.0.CO;2.

Bottom, D. L., Jones, K. K., Cornwell, T. J., Gray, A., and Simenstad, C. A. 2005. Patterns of Chinook salmon migration and residency in the Salmon River estuary (Oregon). Estuar. Coast. Shelf Sci. 64(1): 79-93. doi:10.1016/j.ecss.2005.02.008.

Bradford, M. J. 1995. Comparative review of Pacific salmon survival rates. Can. J. Fish. Aquat. Sci. 52(6): 1327-1338. doi:10.1139/f95-129.

Bradford, M. J., and Taylor, G. C. 1997. Individual variation in dispersal behaviour of newly emerged chinook salmon (Oncorhynchus tshawytscha) from the Upper Fraser River, British Columbia. Can. J. Fish. Aquat. Sci. 54(7): 1585-1592. doi:10.1139/f97-065.

Brannon, E. L., Powell, M. S., Quinn, T. P., and Talbot, A. 2004. Population structure of Columbia River Basin chinook salmon and steelhead trout. Rev. Fish. Sci. 12: 99232. doi: $10.1080 / 10641260490280313$. 
785 Carlson, S. M., and Satterthwaite, W. H. 2011. Weakened portfolio effect in a collapsed 786 salmon population complex. Can. J. Fish. Aquat. Sci. 68(9): 1579-1589. doi:10.1139/f2011-084.

788

789

790

791

792

793

794

795

796

797

798

799

800

801

802

803

804

805

806

807

808

Connor, W. P., Marshall, A. R., Bjornn, T. C. and Burge, H. L. 2001. Growth and longrange dispersal by wild subyearling spring and summer chinook salmon in the Snake River basin. Trans. Am. Fish. Soc. 130(6): 1070-1076. doi:10.1577/15488659(2001)130<1070:GALRDB>2.0.CO;2.

Copeland, T., and Venditti, D. A. 2009. Contribution of three life history types to smolt production in a Chinook salmon (Oncorhynchus tshawytscha) population. Can. J. Fish. Aquat. Sci. 66(10): 1658-1665. Doi:10.1139/F09-110.

Copeland, T., Venditti, D. A., and Barnett, B. R. 2014. The importance of juvenile migration tactics to adult recruitment in stream-type Chinook salmon populations. Trans. Am. Fish. Soc. 143(6): 1460-1475. doi:10.1080/00028487.2014.949011.

Craig, J. A., and Townsend, L. D. 1946. An investigation of fish-maintenance problems in relation to the Willamette Valley Project. Special Scientific Report 33. U. S. Department of the Interior, Fish and Wildlife Service.

Daum, D. W., and Flannery, B. G. 2011. Canadian-origin Chinook salmon rearing in nonnatal U.S. tributary streams of the Yukon River, Alaska. Trans. Am. Fish. Soc. 140(2): 207-220. doi:10.1080/00028487.2011.545004.

Dimick, R.E. and Merryfield, F. 1945. The fishes of the Willamette River system in relation to pollution. Oreg. State Coll. Enginer. Exper. Sta. Bull. Ser. 20: 7-55. Corvallis, OR, USA. Available from http://ir.library.oregonstate.edu/xmlui/bitstream/handle/1957/32301/Bulletin\%20No. \%2020.pdf? sequence=1 [accessed 20 September 2015). 
809 Elmqvist, T., Folke, C., Nyström, M., Peterson, G., Bengtsson, J., Walker, B., and Norberg, J.

810 2003. Response diversity, ecosystem change, and resilience. Front. Ecol. Environ.

811 1(9): 488-494. doi:10.1890/1540-9295(2003)001[0488:RDECAR]2.0.CO;2.

812 Fraser, D. J., Weir, L. K., Bernatchez, L., Hansen, M. M., and Taylor, E. B. 2011. Extent

813 and scale of local adaptation in salmonid fishes: review and meta-analysis. Heredity

814 106(3): 404-420. doi:10.1038/hdy.2010.167.

815 Friesen, T. A., Vile, J. S., and Pribyl, A. L. 2007. Outmigration of juvenile Chinook salmon

816 in the lower Willamette River, Oregon. Northwest Sci. 81(3): 173-190. doi:

817 10.3955/0029-344X-81.3.173.

Good, T. P, Beechie, T. J., McElhany, P., McClure, M. M., and Ruckelshaus, M. H. 2007. Recovery planning for Endangered Species Act-listed Pacific salmon: using science to inform goals and strategies. Fisheries 32(9): 426-440. doi: 10.1577/15488446(2007)32[426:RPFESL]2.0.CO;2.

823

824

825

826

Gregory, S., Ashkenas, L., Haggerty, P., Oetter, D. Wildman, K., Hulse, D., Branscomb, A., and Van Sickle, J. 2002. Riparian vegetation. In Willamette River Basin Planning Atlas: Trajectories of Environmental and Ecological Change. Edited by D. Hulse, S. Gregory, and J. Baker. Oregon State University Press, Corvallis, OR. pp. 40-43. Available from:

829 Gustafson, R. G., Waples, R. S., Myers, J. M., Weitkamp, L. A., Bryant, G. J., Johnson, O. W., and Hard, J. J. 2007. Pacific salmon extinctions: quantifying lost and remaining diversity. Conserv. Biol. 21(4): 1009-1020. doi:10.1111/j.1523-1739.2007.00693.x.

832 Hahn, P. K. J., Bailey, R. E., and Ritchie, A. 2007 Edited by D. H. Johnson, B. M. Shrier, J. 833 S. O’Neal, J. A. Knutzen, X. Augerot, T. A. O’Neil, and T. N. Pearsons. American 
Fisheries Society (in association with State of the Salmon), Bethesda, MD, USA pp 267-324. Available from http://www.stateofthesalmon.org/fieldprotocols/downloads/SFPH_p9.pdf [accessed 20 September 2015]

Healey, M. C. 1991. Life history of Chinook salmon (Oncorhynchus tshawytscha). In Pacific salmon life histories. Edited by C. Groot and L. Margolis. University of British Columbia Press, Vancouver, B.C. pp. 313-393.

Healey, M. C., and Prince, A. 1995. Scales of variation in life history tactics of Pacific salmon and the conservation of phenotype and genotype. Am. Fish. Soc. Symp. 17: 176-184.

Hilborn, R., Quinn, T. P., Schindler, D. E., and Rogers, D. E. 2003. Biocomplexity and fisheries sustainability. Proc. Natl. Acad. Sci. 100(11): 6564-6568. doi:10.1073/pnas.1037274100.

Homolka, K. and Downey, T. W. 1995. Assessment of thermal effects on salmon spawning and fry emergence, Upper McKenzie River, 1992. Oreg. Dep. Fish Wildl. Info. Rep. 95-4, Corvallis, OR. Available from https://nrimp.dfw.state.or.us/CRL/Reports/Info/95-4.pdf [accessed 20 September 2015].

Hulse, D., Gregory, S., and Baker, J. (Editors). 2002. Willamette River Basin Planning Atlas, $2^{\text {nd }}$ edition. Oregon State University Press, Corvallis, OR. Available from http://www.fsl.orst.edu/pnwerc/wrb/Atlas_web_compressed/PDFtoc.html [accessed 20 September 2015]

Irvine, J. R. 1986. Effects of varying discharge on the downstream movement of salmon fry, Oncorhynchus tshawytscha Walbaum. J. Fish Biol. 28(1): 17-28. doi:10.1111/j.10958649.1986.tb05137.x. 
859 Jefferson, A., Grant, G., and Rose, T. 2006. Influence of volcanic history on groundwater 860 patterns on the west slope of the Oregon High Cascades. Water Resources Res. $861 \quad$ 42(12): W12411. doi:10.1029/2005WR004812.

862 Johnson, M. A., and Friesen, T. A. 2014. Genetic diversity and population structure of 863 spring Chinook salmon from the upper Willamette River, Oregon. N. Am. J. Fish. 864 Manage. 34(4): 853-862. doi:10.1080/02755947.2014.920739.

865 Jones, K. K., Cornwell, T. J., Bottom, D. L., Campbell, L. A., and Stein, S. 2014. The 866 contribution of estuary-resident life histories to the return of adult Oncorhynchus 867 kisutch. J. Fish Biol. 85(1): 52-80. doi:10.1111/jfb.12380.

868 Jorgensen, J. C., McClure, M. M., Sheer, M. B., and Munn, N. L. 2013. Combined effects of 869 climate change and bank stabilization on shallow water habitats of Chinook salmon. $870 \quad$ Conserv. Biol. 27(6): 1201-1211. doi:10.1111/cobi.12168.

871 Kerr, L. A., Cadrin, S. X., and Secor, D. H. 2010. The role of spatial dynamics in the 872 stability, resilience, and productivity of an estuarine fish population. Ecol. Appl. $873 \quad 20(2): 497-507$. doi:10.1890/08-1382.1.

874 Kocik, J. F., and Ferreri, C. P. 1998. Juvenile production variation in salmonids: population 875 dynamics, habitat, and the role of spatial relationships. Can. J. Fish. Aquat. Sci. $876 \quad$ 55(S1): 191-200. doi:10.1139/d98-015.

877 Kraus, R. T., and Secor, D. H. 2004. Dynamics of white perch Morone americana 878 population contingents in the Patuxent River estuary, Maryland, USA. Mar. Ecol. 879 Progr. Ser. 279: 247-259. doi:10.3554/meps279247.

880 Ledgerwood, R. D., Ryan, B. A., Dawley, E. M., Nunnallee, E. P. and Ferguson, J. W. 2004. 881 A surface trawl to detect migrating juvenile salmonids tagged with passive integrated 882 transponder tags. N. Am. J. Fish. Manage. 24(2):440-451. doi:440-451. 10.1577/M0$883 \quad 071.1$. 
884 Levings, C. D., and Lauzier, R. B. 1991. Extensive use of the Fraser River basin as winter 885 habitat by juvenile chinook salmon (Oncorhynchus tshawytscha). Can. J. Zool. 69(7): 1759-1767. doi:10.1139/z91-245.

Matala, A. P., Hess, J. E., and Narum, S. R. 2011. Resolving adaptive and demographic divergence among Chinook salmon populations in the Columbia River basin. Trans. Am. Fish. Soc. 140(3): 783-807. doi: 10.1080/00028487.2011.588092.

Mattson, C. R. 1962. Early life history of Willamette River spring Chinook salmon. Fish Commission of Oregon, Portland.

McElhany, P., Backman, T., Busack, C., Heppell, S., Kolmes, S., Maule, A., Myers, J., 893 Rawding, D., Shively, D., Steel, A., Steward, C., and Whitesel, T. 2003. Interim

Miller, J. A., Gray, A., and Merz, J. 2010. Quantifying the contribution of juvenile report on viability criteria for Willamette and lower Columbia basin Pacific salmonids. U.S. Dep. Commer. NOAA Willamette/Lower Columbia Technical migratory phenotypes in a population of Chinook salmon Oncorhynchus tshawytscha. and its importance to population stability and persistence of a migratory fish: steelhead in two large North American watersheds. J. Anim. Ecol. 83(5): 1035-1046. doi:10.1111/1365-2656.12212. 
909 Montgomery, D. R. 2000. Coevolution of the Pacific salmon and Pacific Rim topography.

910 Geology 28(2):1107-1110. doi: 10.1130/0091-7613(2000)28<1107:COTPSA>

$911 \quad 2.0 . \mathrm{CO} ; 2$.

912 Moran, P., Teel, D. J., Banks, M. A., Beacham, T. D., Bellinger, M. R., Blankenship, S. M.,

913 Candy, J. R., Garza, J. C., Hess, J. E., Narum, S. R., Seeb, L. W., Templin, W. D.,

914 Wallace, C. G. \& Smith, C. T. 2013. Divergent life history races do not represent

915 Chinook salmon coast wide: the importance of scale in Quaternary biogeography.

916 Can. J. Fish. Aquat. Sci. 70, 415-435. doi: 10.1139/cjfas-2012-0135.

917 Murphy, M. L., Koski, K. V., Lorenz, J. M., and Thedinga, J. F. 1997. Downstream

918 migrations of juvenile Pacific salmon (Oncorhynchus spp.) in a glacial transboundary

919 river. Can. J. Fish. Aquat. Sci. 54, 2837-2846. doi:10.1139/f97-178.

920 Murray, C. B., and Rosenau, M. L. 1989. Rearing of juvenile chinook salmon in nonnatal

921 tributaries of the lower Fraser River, British Columbia. Trans. Am. Fish. Soc. 118(3):

922 284-289. doi:10.1577/1548-8659(1989)118<0284:ROJCSI >2.3.CO;2.

923 Myers, J. M., Kope, R. G., Bryant, G. J., Teel, D., Lierheimer, L. J., Wainwright, T. C.,

924 Grant, W. S., Waknitz, F. W., Neely, K., Lindley, S.T., and Waples, R. S. 1998.

925 Status review of Chinook salmon from Washington, Idaho, Oregon, and California.

926 U.S. Dep. Commer. NOAA Tech. Memo. NMFS-NWFSC-35. Available from

927 http://www.westcoast.fisheries.noaa.gov/publications/status_reviews/salmon_steelhea

928 d/chinook/sr1998-chinook1.pdf [accessed 20 September 2015].

929 Narum, S. R., Hess, J. E., and Matala. A. P. 2010. Examining genetic lineages of Chinook

930 salmon in the Columbia River basin. Trans. Am. Fish. Soc. 139(5): 1465-1477. doi:

$931 \quad 10.1577 / \mathrm{T} 09-150.1$.

932 NMFS (National Marine Fisheries Service). 1999. Threatened status for three Chinook

933 salmon Evolutionarily Significant Units (ESUs) in Washington and Oregon, and 
endangered status for one Chinook ESU in Washington. U.S. Federal Register 64:56

935 (March 24, 1999): 14308-14328. Available from http://www.westcoast.fisheries.noaa.gov/publications/frn/1999/64fr14308.pdf [accessed 20 September 2015]

NOAA (National Oceanic and Atmospheric Administration). 1981. Columbia River fisheries development program. Informational Booklet. Available from:

ODFW (Oregon Department of Fish and Wildlife) and NMFS (National Marine Fisheries Service). 2011. Upper Willamette River conservation and recovery plan for Chinook salmon and steelhead. Final - August 5, 2011. Available from:

http://www.westcoast.fisheries.noaa.gov/publications/recovery_planning/salmon_steelhead/d omains/willamette_lowercol/willamette/will-final-plan.pdf [accessed 20 September 2015]

Parkhurst, Z. E., Bryant, F. G., Nielson, R. S. 1950. Survey of the Columbia River and its tribuataries, Part III. U. S. Fish Wildl. Ser., Spec. Sci. Rep. Fish., No. 36. Available from: http://docs.streamnetlibrary.org/USFWS/ssrf-036.pdf [accessed 28 October 2015]

Quinn, T. P. 2005. The behavior and ecology of Pacific salmon and trout. University of Washington Press, Seattle, WA, USA.

Quinn, T. P., Kinnison, M. T., and Unwin, M. J. 2001. Evolution of chinook salmon (Oncorhynchus tshawytscha) in New Zealand: pattern, rate, and process. Genetica 112(1): 493-513. doi 10.1023/A:1013348024063.

PTSC (PIT Tag Steering Committee). 2014. PIT tag marking procedures manual, Version 3.0. Pacific States Marine Fisheries Commission, Portland, Oregon. Available from 

http://www.ptagis.org/docs/default-source/ptagis-program-documents/2014-mark-

$960 \quad$ procedures-manual.pdf?sfvrsn=2 [accessed 20 September 2015]

961 Reimers, P. E. 1973. The length of residence of juvenile fall chinook in the Sixes River,

962 Oregon. Oreg. Fish Comm. Res. Rep. 4: 3-42. Corvallis, OR. Available from

963 http://ir.library.oregonstate.edu/xmlui/handle/1957/21340 [accessed 20 September

964 2015].

965 Rogers, L. A., and Schindler, D. E. 2008. Asynchrony in population dynamics of sockeye

966 salmon in southwest Alaska. Oikos 117(10): 1578-1586. doi:10.1111/j.0030-

$967 \quad$ 1299.2008.16758.x.

968 Ruckelshaus, M. H., Levin, P., Johnson, J. B., and Kareiva, P. M. 2002. The Pacific salmon

969 wars: what science brings to the challenge of recovering species. Annu. Rev. Ecol.

970 Syst. 33(2002): 665-706. doi:10.1146/annurev.ecolsys.33.010802.150504.

971 Ruff, C. P, Schindler, D. E., Armstrong, J. B., Bentley, K. T., Brooks, G. T., Holtgrieve, G.

972 W., McGlauflin, M. T., Torgersen, C. E., and Seeb, J. E. 2011. Temperature-

973 associated population diversity in salmon confers benefits to mobile consumers.

974 Ecology 92:2073-2084. http://dx.doi.org/10.1890/10-1762.1.

975 Schindler, D. E., Hilborn, R., Chasco, B., Boatright, C. P., Quinn, T. P., Rogers, L. A., and

976 Webster, M. S. 2010. Population diversity and the portfolio effect in an exploited

977 species. Nature 465(7298): 609-612. doi:10.1038/nature09060.

978 Schindler, D. E., Armstrong, J. B., and Reed, T. E. 2015. The portfolio concept in ecology

979 and evolution. Front. Ecol. Environ. 13(5):257-263. doi:10.1890/140275.

980 Schroeder, R. K., Kenaston, K. R., and Krentz, L. K. 2005. Spring Chinook salmon in the

981 Willamette and Sandy Rivers. Oreg. Dep. Fish Wildl. Fish Res. Proj. Rep. F-163-R-

982 10. Salem, OR. Available from 

https://nrimp.dfw.state.or.us/CRL/Reports/AnnPro/Annual_report05_corrected_web.p

984 df [accessed 20 September 2015].

985 Sedell, J. R. and Froggatt, J. L. 1984. Importance of streamside forests to large rivers: the 986

Stearns, S. C. 1976. Life-history tactics: a review of the ideas. Quart. Rev. Biol. 51(1): 3-47. http://www.jstor.org/stable/2825234. salmon, Oncorhynchus tshawytscha. J. Anim. Ecol. 59(2): 455-468. doi:10.2307/4874. 
1006 Thomas, A. E., Banks, J. L., and Greenland, D. C. 1969. Effect of yolk sac absorption on the 1007 swimming ability of fall chinook salmon. Trans. Am. Fish. Soc. 98(3): 406-410. 1008 doi:10.1577/1548-8659(1969)98[406:EOYSAO]2.0.CO;2.

1009 Thorson, J. T., Scheuerell, M. D., Buhle, E. R., and Copeland, T. 2014. Spatial variation 1010 buffers temporal fluctuations in early juvenile survival for an endangered Pacific 1011 salmon. J. Anim. Ecol. 83(1): 157-167. doi: 10.1111/1365-2656.12117.

1012 Wallick, J.R., Grant, G.E., Lancaster, S.T., Bolte, J.P., and Denlinger, R.P. 2007. Patterns 1013 and controls on historical channel change in the Willamette River, Oregon, USA. In 1014 Large rivers: geomorphology and management. Edited by A. Gupta. John Wiley and 1015 Sons, Ltd., Chichester, UK. pp. 491-516. doi:10.1002/9780470723722.ch23.

1016 Walsworth, T. E., Schindler, D. E., Griffiths, J. R., and Zimmerman, C. E. 2014. Diverse 1017 juvenile life-history behaviours contribute to the spawning stock of an anadromous 1018 fish population. Ecol. Freshw. Fish 24(2): 204-213. doi:10.1111/eff.12135.

1019 Waples, R. S., Gustafson, R. G., Weitkamp, L. A., Myers, J. M., Johnson, O. W., Busby, P. 1020 J., Hard, J. J., Bryant, G. J., Waknitz, F. W., Nelly, K., Teel, D., Grant, W. S., Winans, G. A., Phelps, S., Marshall, A., and Baker, B. M. 2001. Characterizing diversity in salmon from the Pacific Northwest. J. Fish Biol. 59(Supplement A): 1-41.

1024 Waples, R. S., Teel, D. J., Myers, J. M., and Marshall, A. R. 2004. Life-history divergence 1025 in Chinook salmon: historic contingency and parallel evolution. Evolution. 58(2): 1026 386-403. doi:10.1111/j.0014-3820.2004.tb01654.x.

1027 Waples, R. S., Pess, G. R., and Beechie, T. 2008. Evolutionary history of Pacific salmon in 1028 dynamic environments. Evol. Appl. 1(2): 189-206. doi:10.1111/j.17521029 4571.2008.00023.x. 
1030 Waples, R.S., Beechie, T., and Pess, G.R. 2009. Evolutionary history, habitat disturbance

1031 regimes, and anthropogenic changes: what do these mean for resilience of Pacific

1032 salmon populations? [online]. Ecol. and Soc. 14(1):3.

1033 http://www.ecologyandsociety.org/vol14/iss1/art3/

1034 Watters, J. V., Lema, S. C., and Nevitt, G. A. 2003. Phenotype management: a new

1035 approach to habitat restoration. Biol. Conserv. 112(3): 435-445. doi:10.1016/S0006-

$1036 \quad 3207(02) 00343-9$.

1037 Willis, R. A., Collins, M. D., and Sams, R. E. 1960. Environmental survey report pertaining

1038 to salmon and steelhead in certain rivers of eastern Oregon and the Willamette River

1039 and its tributaries. Part II. Survey reports of the Willamette River and its tributaries.

1040 Fish Comm. Oreg., Clackamas, Oreg. Available from:

1041 http://www.streamnetlibrary.org/?page_id=620 [accessed 28 October 2015]

1042 Zakel, J. C., and Reed, D. W. 1984. Downstream migration of fish at Leaburg Dam,

1043 McKenzie River, Oregon, 1980 to 1983. Oreg. Dep. Fish Wildl. Info. Rep. 84-13.

1044 Corvallis, OR. Available from https://nrimp.dfw.state.or.us/CRL/Reports/Info/84-

$1045 \quad \underline{13 . p d f}$ [accessed 28 October 28, 2015] 
1 Table 1. Number of juvenile Chinook salmon given PIT tags and released in the Willamette River basin upstream of Willamette Falls, 2004-

22013 brood years. Movers were subyearling Chinook salmon tagged and released in May-July; stayers in the McKenzie River were tagged and

3 released at Leaburg Dam as they migrated downstream in October-January (fall migrant) and February-May (spring migrant), or upstream in

4 Reach A-1 in July-September.

\begin{tabular}{|c|c|c|c|c|c|c|c|c|c|}
\hline \multirow[b]{2}{*}{$\begin{array}{c}\text { Brood } \\
\text { year }\end{array}$} & \multicolumn{6}{|c|}{ Movers } & \multicolumn{3}{|c|}{ Stayers } \\
\hline & $\begin{array}{c}\text { McKenzie } \\
\text { Reach B }\end{array}$ & $\begin{array}{c}\text { Willamette } \\
\text { Reach D }\end{array}$ & $\begin{array}{l}\text { S. Santiam } \\
\text { Reach B }\end{array}$ & $\begin{array}{l}\text { N. Santiam } \\
\text { Reach B }\end{array}$ & $\begin{array}{l}\text { Santiam } \\
\text { Reach B }\end{array}$ & $\begin{array}{c}\text { Willamette } \\
\text { Reach E }\end{array}$ & $\begin{array}{c}\text { Leaburg } \\
\text { fall migrant }\end{array}$ & $\begin{array}{c}\text { Leaburg } \\
\text { spring migrant }\end{array}$ & $\begin{array}{l}\text { McKenzie } \\
\text { Reach A-1 }\end{array}$ \\
\hline 2004 & 1967 & 2659 & & 187 & 397 & 638 & 3268 & 626 & \\
\hline 2005 & 1592 & 1821 & 2503 & 1636 & 1488 & 578 & 3177 & 644 & \\
\hline 2006 & 1963 & 2039 & 1966 & 1419 & 1815 & 1956 & 4256 & 1663 & \\
\hline 2007 & 6600 & 7415 & 2498 & 1900 & 590 & 4390 & 4593 & 1301 & \\
\hline 2008 & 2829 & 2842 & 1762 & 1542 & 1577 & 2269 & 2211 & 1877 & \\
\hline 2009 & 1109 & 2457 & 1721 & 2178 & 948 & 3659 & 4027 & 813 & \\
\hline 2010 & 4713 & 5136 & 2825 & 1934 & 770 & 2648 & 3601 & 278 & 1970 \\
\hline 2011 & 2968 & 7965 & 1212 & 734 & & 3276 & 3517 & 2311 & 3023 \\
\hline 2012 & 1177 & 3107 & 513 & 534 & 445 & 3410 & 5253 & 466 & 2906 \\
\hline 2013 & 2054 & 2825 & & & & 1773 & 2162 & 395 & 842 \\
\hline
\end{tabular}

5 
6 Table 2. Mean residence time of juvenile Chinook salmon within and downstream of natal

7 areas in the Willamette River basin for movers (migrated as fry shortly after emergence) and

8 stayers (remained in natal areas at least through their first summer of life). Residence time

9 was estimated from a combination of emergence dates, capture dates, and days between

10 release of tagged fish and subsequent detection. We estimated that the residence time within

11 natal areas for movers was as little as 4 days based on emergence date and first capture of fry

12 downstream of natal areas, and was up to 30 days based on the difference between peak

13 emergence date and peak catch of fry at Leaburg Dam.

\begin{tabular}{|c|c|c|c|c|}
\hline \multirow[b]{2}{*}{ Migrant type, smolt type (n) } & \multicolumn{2}{|c|}{ Natal rearing } & \multicolumn{2}{|c|}{ Downstream rearing } \\
\hline & Mean & SD & Mean & SD \\
\hline \multicolumn{5}{|l|}{ Mover } \\
\hline Subyearling (2237) & & & 125.5 & 15.2 \\
\hline Autumn (242) & & & 245.3 & 25.2 \\
\hline Yearling (97) & & & 384.4 & 23.4 \\
\hline \multicolumn{5}{|l|}{ Stayer-fall migrant } \\
\hline Autumn (212) & 267.8 & 14.9 & 33.3 & 24.1 \\
\hline Yearling (922) & 283.7 & 25.8 & 119.7 & 31.2 \\
\hline \multicolumn{5}{|l|}{ Stayer-spring migrant } \\
\hline Yearling (867) & 394.8 & 26.0 & 47.8 & 22.9 \\
\hline
\end{tabular}

14

15 
16 Table 3. Composition (\%) by life history of juvenile Chinook salmon migrating past

17 Willamette Falls based on the detection of tagged fish from the McKenzie River population.

18 Tag groups were: movers (downstream of natal areas in first spring and summer of life),

19 stayer-fall migrants (migrating from natal areas in October-January), and stayer-spring

20 migrants (migrating from natal areas in February-May). Smolt types at Willamette Falls were

21 subyearling (June-July), autumn (October-January), and yearling (February-May). Excludes

222005 and 2010 brood years because shutdowns at Willamette Falls or Leaburg Dam resulted

23 in incomplete data.

\begin{tabular}{|c|c|c|c|c|c|c|}
\hline \multirow{3}{*}{$\begin{array}{c}\text { Brood } \\
\text { year }\end{array}$} & \multicolumn{6}{|c|}{ Tag group, smolt type (\%) } \\
\hline & \multicolumn{3}{|c|}{ Mover } & \multicolumn{2}{|c|}{ Stayer-fall } & \multirow{2}{*}{$\begin{array}{c}\text { Stayer-spring } \\
\text { Yearling }\end{array}$} \\
\hline & Subyearling & Autumn & Yearling & Autumn & Yearling & \\
\hline 2004 & 11.0 & 3.3 & 0.7 & 15.0 & 12.3 & 57.7 \\
\hline 2006 & 6.7 & 0.8 & 1.6 & 7.3 & 12.0 & 71.6 \\
\hline 2007 & 13.0 & 10.1 & 4.7 & 8.0 & 14.5 & 49.7 \\
\hline 2008 & 15.3 & 3.5 & 0.4 & 6.3 & 22.9 & 51.6 \\
\hline 2009 & 34.2 & 7.9 & 2.4 & 5.1 & 11.7 & 38.7 \\
\hline 2011 & 29.0 & 1.3 & 0.7 & 3.2 & 24.8 & 41.0 \\
\hline 2012 & 11.4 & 0.4 & 0.4 & 8.8 & 26.9 & 52.1 \\
\hline 2013 & 23.7 & 1.1 & 1.0 & 18.2 & 24.5 & 31.5 \\
\hline
\end{tabular}

24 
26 Table 4. Pearson's correlation coefficients of pairwise comparisons among the expanded

27 number of six life histories of juvenile Chinook salmon detected at Willamette Falls over

28 eight brood years. Life histories are labeled as migration from natal areas (movers = M;

29 stayers migrating from natal areas in fall or spring $=\mathrm{S}_{\mathrm{F}}$ or $\mathrm{S}_{\mathrm{S}}$ ); and smolt type (subyearling $=$

$30 \mathrm{~S}$; autumn $=\mathrm{A}$; yearling $=\mathrm{Y})$. Significant differences are denoted for $\mathrm{P}<0.05(*)$ and $\mathrm{P}<$

$310.01(* *)$.

\begin{tabular}{lccccc}
\hline & \multicolumn{5}{c}{ Life history } \\
\cline { 2 - 6 } Life history & $\mathrm{M}-\mathrm{A}$ & $\mathrm{M}-\mathrm{Y}$ & $\mathrm{S}_{\mathrm{F}}-\mathrm{A}$ & $\mathrm{S}_{\mathrm{F}}-\mathrm{Y}$ & $\mathrm{S}_{\mathrm{S}}-\mathrm{Y}$ \\
\hline $\mathrm{M}-\mathrm{S}$ & 0.45 & 0.31 & 0.17 & 0.31 & 0.08 \\
$\mathrm{M}-\mathrm{A}$ & & $0.88^{* *}$ & -0.26 & -0.32 & -0.06 \\
$\mathrm{M}-\mathrm{Y}$ & & -0.11 & -0.28 & -0.09 \\
$\mathrm{~S}_{\mathrm{F}}-\mathrm{A}$ & & & 0.57 & 0.20 \\
$\mathrm{~S}_{\mathrm{F}}-\mathrm{Y}$ & & & & $0.73^{*}$ \\
\hline
\end{tabular}

32 
1 Fig. 1. Willamette River Basin in Oregon, USA, showing flood control dams, sampling

2 reaches, and PIT tag detection sites at Leaburg Dam on the McKenzie River and at

3 Willamette Falls.

5 Fig. 2. Dates of the first catch (o) of Chinook salmon fry by pole seines in three tributaries of

6 the Willamette River basin upstream of Willamette Falls within spawning reaches (A) or

7 downstream (B) and in three reaches of the Willamette River, and dates when fry were caught

8 in $\geq 75 \%$ of sites in the Willamette River $(\bullet), 2011$ brood year. Bracketed lines are dates for

9 the range of temperature units at first fry sampling (850 ATU) through estimated emergence

10 (1 000 ATU) for early spawning (first $5 \%$ of redds), and triangles $(\triangle)$ are estimated

11 emergence dates for peak spawning. See Methods and Figure 1 (map) for description and

12 location of reaches.

14 Fig. 3. Mean (and range) of the median day of passage at Willamette Falls from expanded 15 detections of tagged juvenile Chinook salmon that were captured with seines in six areas of the Willamette River basin downstream of spawning areas (movers), captured with a trap at

17 Leaburg Dam on the McKenzie River in October-January (stayers-fall migrant) or February-

18 May (stayers-spring migrant), or captured with seines upstream of Leaburg Dam in Reach A-

19 1, 2004-2013 brood years. Number of brood years for each release group is in parentheses

20 and years with $<25$ unexpanded detections were excluded.

22 Fig. 4. Emigration timing of juvenile Chinook salmon from the upper McKenzie River

23 subbasin based on the mean biweekly catch rate $\left(\right.$ fish $\left.\cdot \mathrm{d}^{-1}\right)$ at the Leaburg Dam bypass trap ( $\bullet$,

24 solid line), and emigration timing from the Willamette River based on the mean biweekly 
25 detections (expanded) of tagged McKenzie fish at Willamette Falls (o, dashed line), 2004262013 brood years.

Fig. 5. Migratory pathways of juvenile Chinook salmon from spawning areas to Willamette

Falls for two phenotypes: fish that migrate from natal areas as emergent fry (movers = gray lines) and those that rear in spawning areas (stayers = black lines). Estimates of the percentage of fish expressing different migratory behaviors were from the detection of tagged juvenile Chinook salmon from the McKenzie River population. Primary migratory pathways are represented by thick lines and arrows, and smolt types are in boxes with thick borders and bold font; secondary pathways are narrow lines and arrows or dashed lines, and secondary migrant types are in boxes with dashed borders and italics. Percentages for the pathways are additive and percentages in boxes below $\mathrm{X}$-axis are the mean contribution of three smolt types to the estimated smolt production, 2004-2013 brood years.

Fig. 6. Mean coefficient of variation $(\mathrm{CV})$ and proportion of the contribution to smolts for six life histories of juvenile Chinook salmon (McKenzie River population) over eight brood years based on the expanded number of detections at Willamette Falls standardized per 1000 fish tagged and released. Life histories are labeled as migration from natal reaches and smolt type: mover $(\mathrm{M})$, stayer that migrated in fall $\left(\mathrm{S}_{\mathrm{F}}\right)$, and stayer that migrated in spring $\left(\mathrm{S}_{\mathrm{S}}\right)$; subyearling smolt (S), autumn smolt (A), and yearling smolt (Y). The right panel is the calculated CV for the total indexed smolt production $(\bullet)$ and the predicted $\mathrm{CV}$ of the migrant population (o) estimated from the weighted average CV of the six life histories (Moore et al. 2014). 


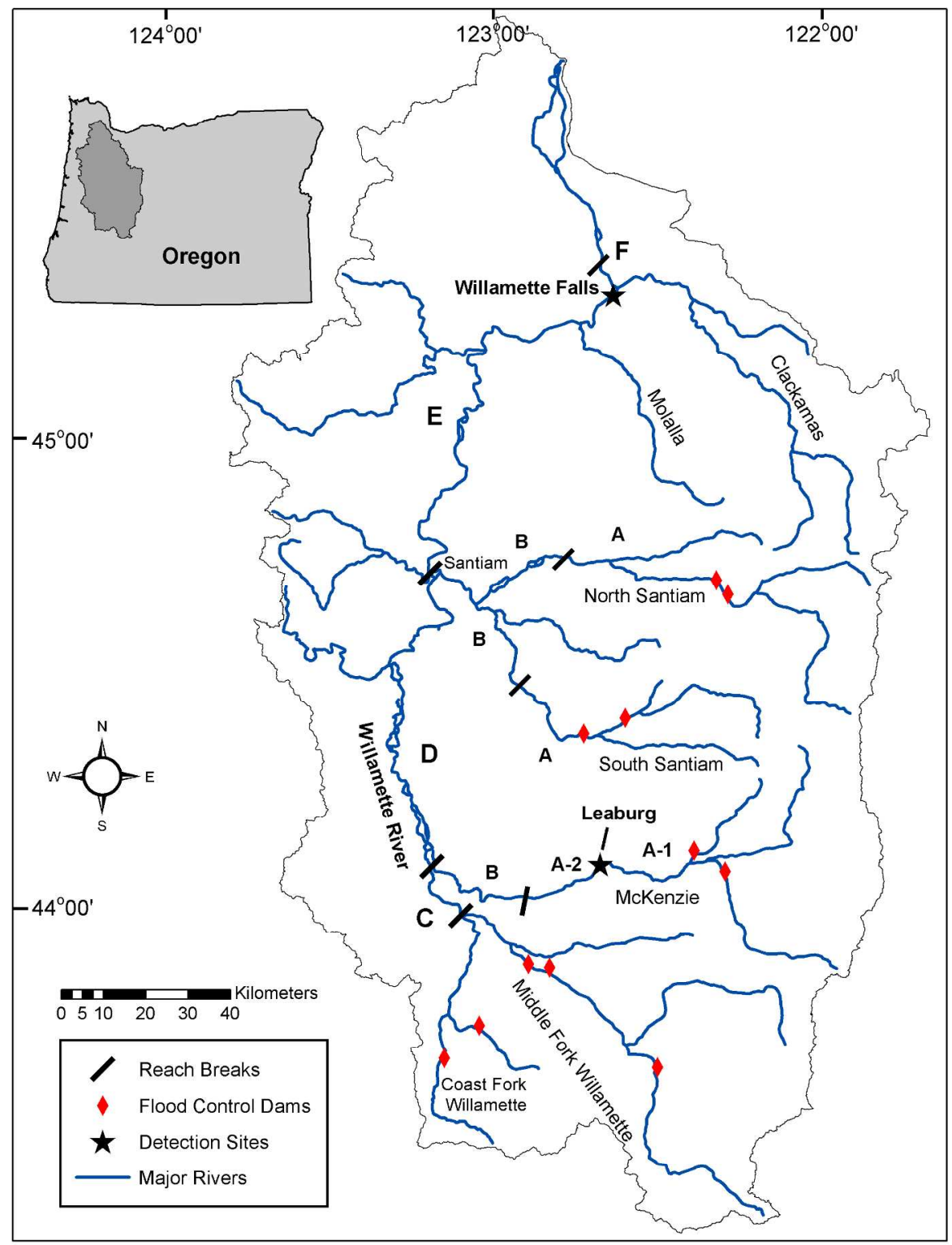

Fig. 1. Willamette River Basin in Oregon, USA, showing flood control dams, sampling reaches, and PIT tag detection sites at Leaburg Dam on the McKenzie River and at Willamette Falls. $215 \times 279 \mathrm{~mm}(300 \times 300 \mathrm{DPI})$ 


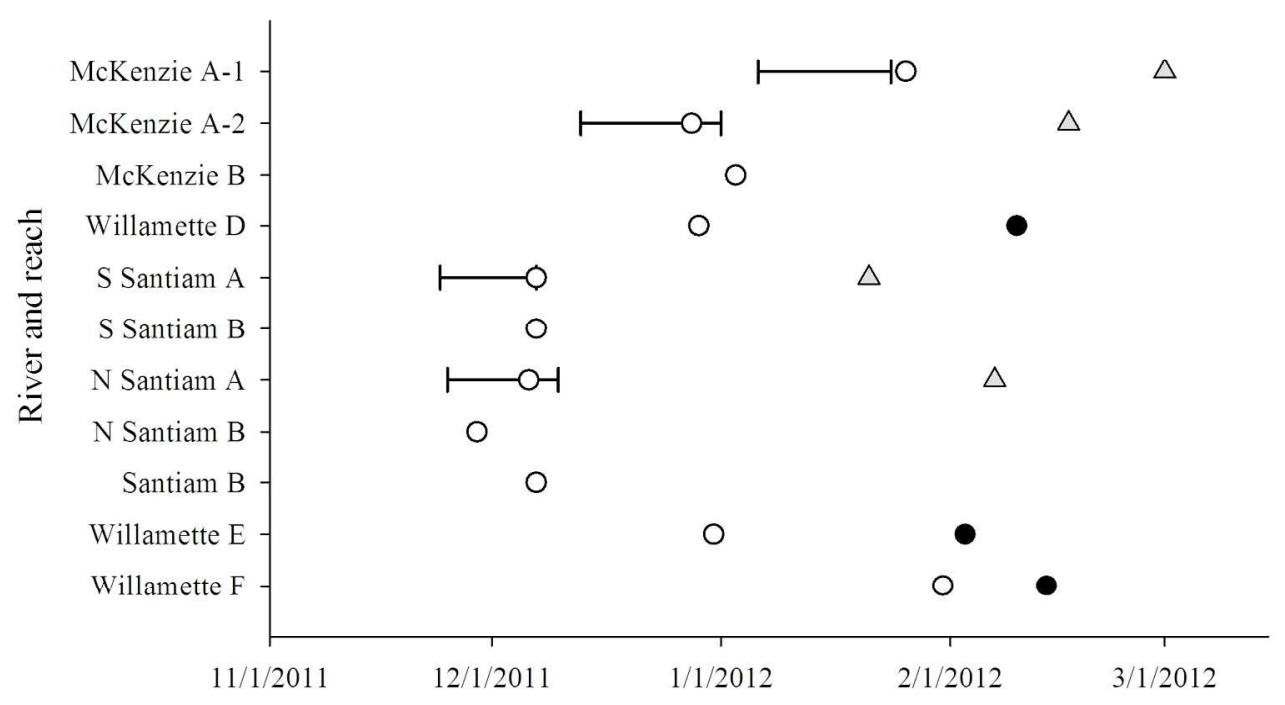

Fig. 2. First catch ( 0 ) of fry and occupancy of sites in the Willamette River (•).Bracketed lines are 850-1000 ATU for emergence time of early spawners, and triangles $(\mathbf{\Lambda})$ are estimated emergence time for peak spawning.

$186 \times 113 \mathrm{~mm}(300 \times 300$ DPI $)$ 


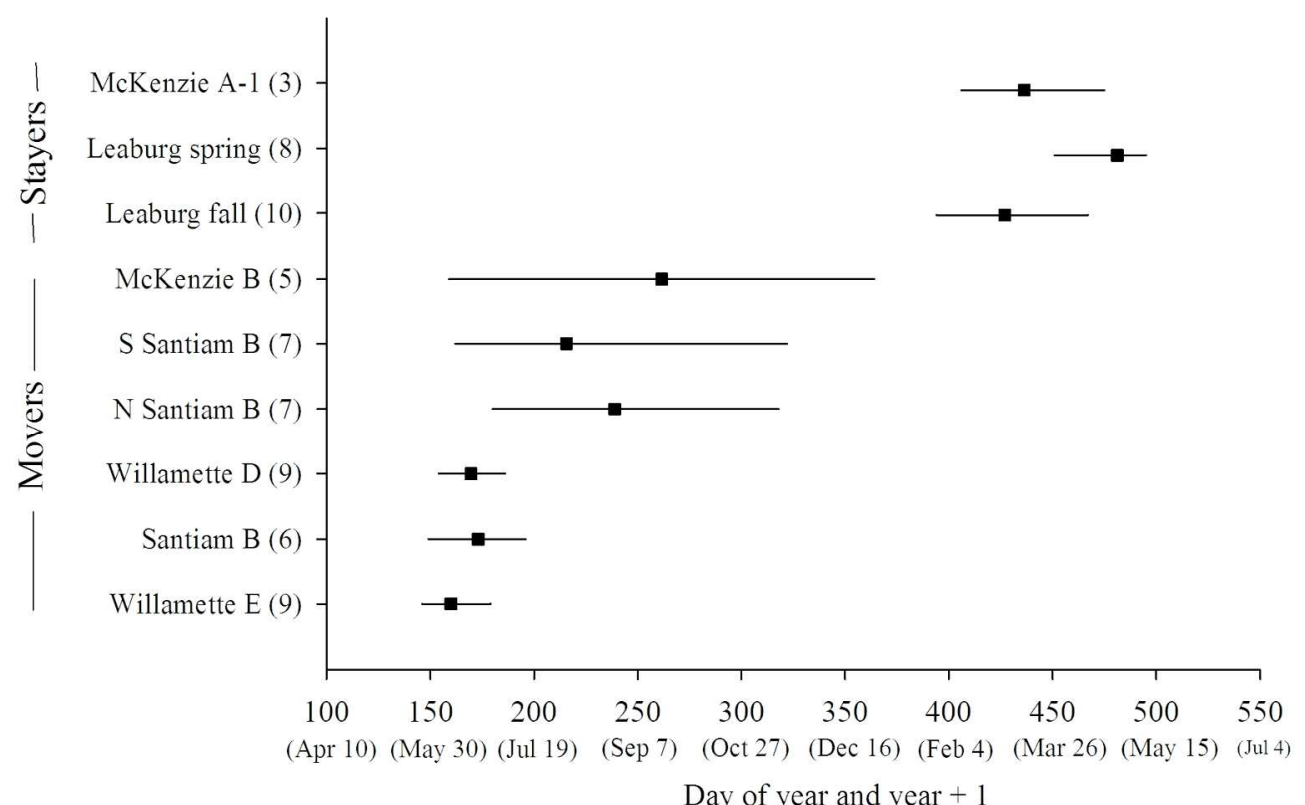

Fig. 3. Passage timing of tagged fish at Willamette Falls for two migratory phenotypes. $176 \times 121 \mathrm{~mm}(300 \times 300$ DPI $)$ 


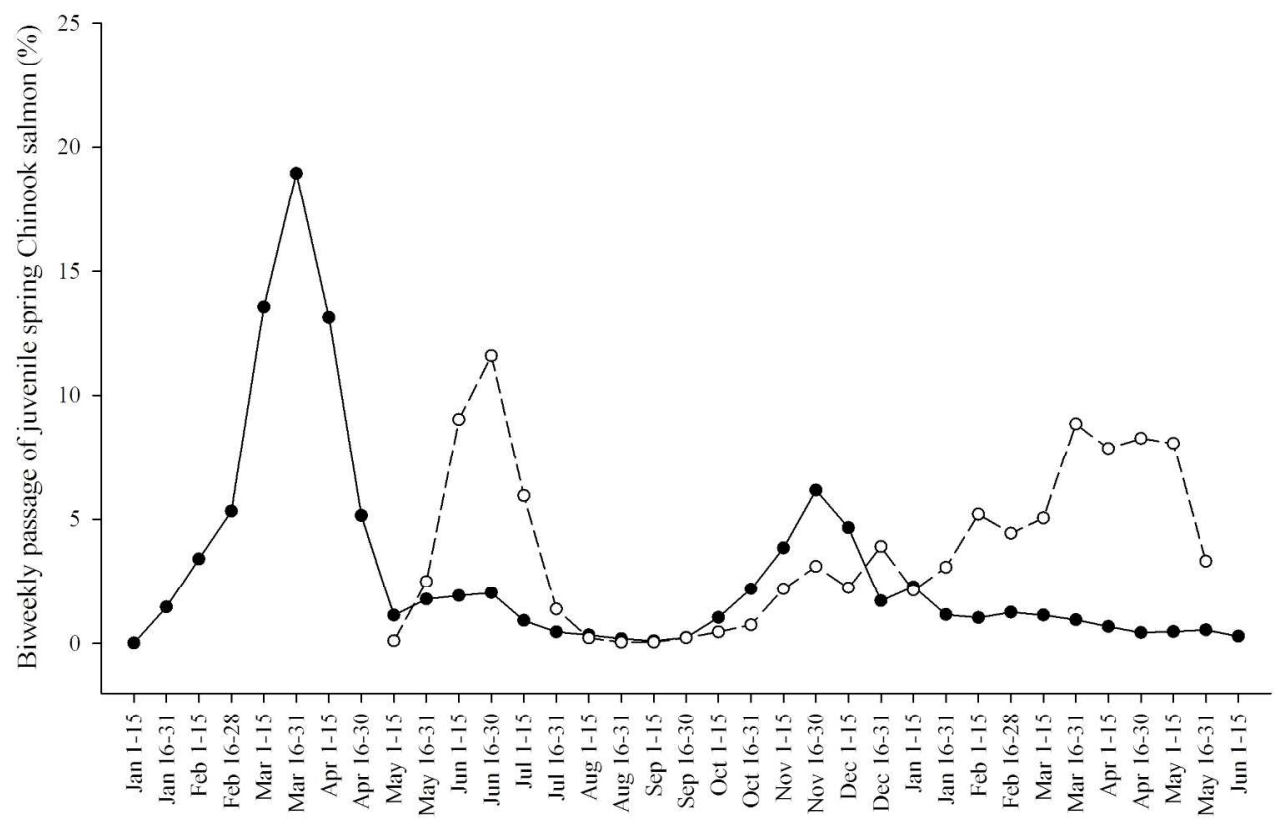

Emigration timing of juvenile Chinook salmon from the upper McKenzie River subbasin based on the mean

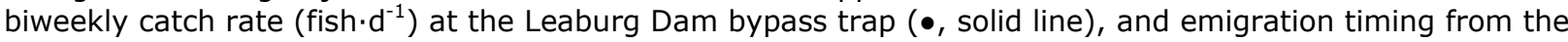
Willamette River based on the mean biweekly detections (expanded) of tagged McKenzie fish at Willamette Falls (o, dashed line), 2004-2013 brood years. $195 \times 137 \mathrm{~mm}(300 \times 300 \mathrm{DPI})$ 


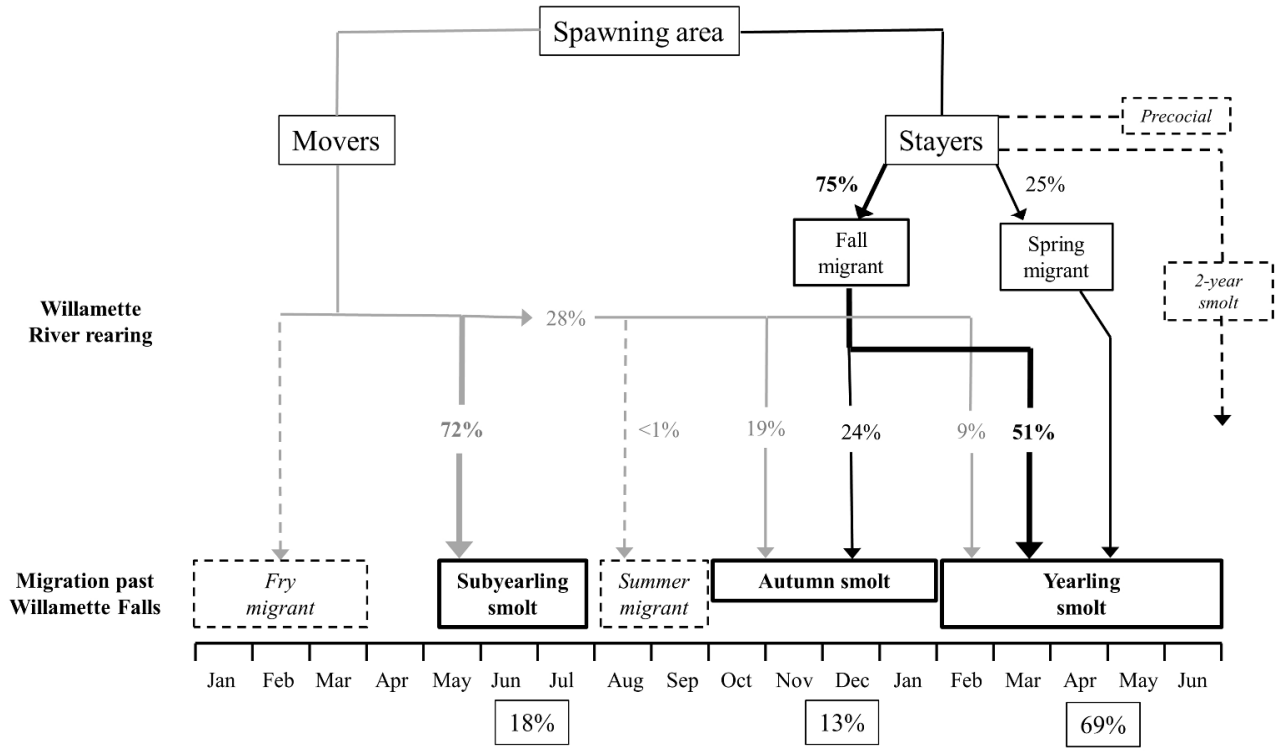

Migratory pathways of juvenile Chinook salmon from spawning areas to Willamette Falls for two phenotypes: fish that migrate from natal areas as emergent fry (movers = gray lines) and those that rear in spawning areas (stayers $=$ black lines). Estimates of the percentage of fish expressing different migratory behaviors were from the detection of tagged juvenile Chinook salmon from the McKenzie River population. Primary migratory pathways are represented by thick lines and arrows, and smolt types are in boxes with thick borders and bold font; secondary pathways are narrow lines and arrows or dashed lines, and secondary migrant types are in boxes with dashed borders and italics. Percentages for the pathways are additive and percentages in boxes below $\mathrm{X}$-axis are the mean contribution of three smolt types to the estimated smolt production, 2004-2013 brood years.

$254 \times 190 \mathrm{~mm}$ (300 x 300 DPI) 


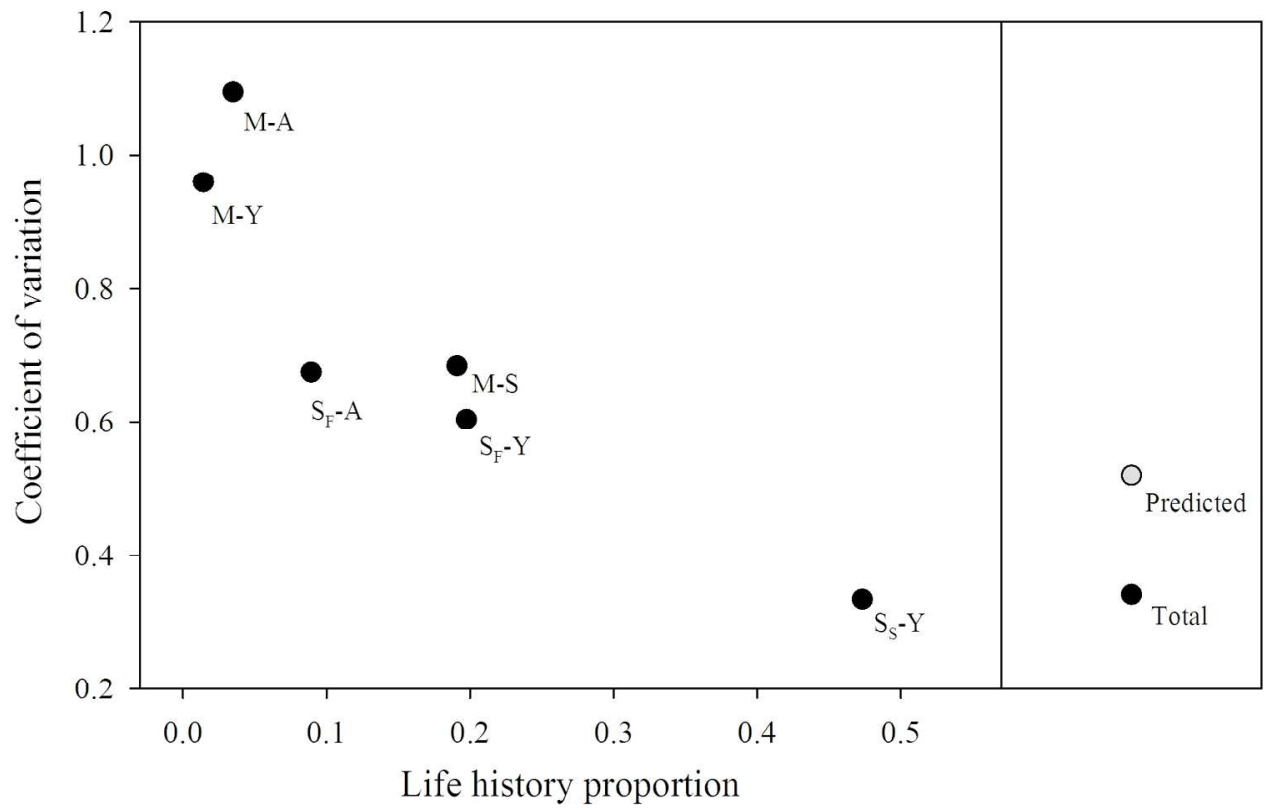

Mean coefficient of variation (CV) and proportion of the contribution to smolts for six life histories of juvenile Chinook salmon (McKenzie River population) over eight brood years based on the expanded number of detections at Willamette Falls standardized per 1000 fish tagged and released. Life histories are labeled as migration from natal reaches and smolt type: mover $(M)$, stayer that migrated in fall $\left(S_{F}\right)$, and stayer that migrated in spring $\left(\mathrm{S}_{\mathrm{S}}\right)$; subyearling smolt $(\mathrm{S})$, autumn smolt $(\mathrm{A})$, and yearling smolt $(\mathrm{Y})$. The right panel is the calculated CV for the total indexed smolt production $(\bullet)$ and the predicted CV of the migrant population

$(\bullet)$ estimated from the weighted average CV of the six life histories (Moore et al. 2014).

$172 \times 118 \mathrm{~mm}(300 \times 300 \mathrm{DPI})$ 


\section{Appendix - Effect of Flow on Expansion of Tag Detections}

2 Because the volume of river flow diverted to the hydroelectric plant and fish bypass at

3 Willamette Falls is relatively constant $\left(177 \mathrm{~m}^{3} \cdot \mathrm{s}^{-1}\right)$, we assumed the entrainment of migrating

4 juvenile salmon would be inversely proportional to flow (i.e., decrease at increasing flow).

5 We used the proportion of total river flow diverted into the plant to expand detections of

6 tagged fish at the falls. We also developed a measure of relative fish passage $\left(\mathrm{P}_{\mathrm{r}}\right)$ to account

7 for changes in the relationship between flow and entrainment at different ranges of flow. Our

8 estimates for $\mathrm{P}_{\mathrm{r}}$ were derived from controlled releases of radio-tagged fish by Portland

9 General Electric biologists and PIT-tagged fish by ODFW biologists. Tagged hatchery spring

10 Chinook salmon were released upstream of the falls between $c .280$ and $1135 \mathrm{~m}^{3} \cdot \mathrm{s}^{-1}$. The

11 mean detection rates of tagged fish for multiple test releases at similar flows were used to

12 develop three values of $\mathrm{P}_{\mathrm{r}}: 1.0\left(<425 \mathrm{~m}^{3} \cdot \mathrm{s}^{-1}\right), 0.8\left(425-707 \mathrm{~m}^{3} \cdot \mathrm{s}^{-1}\right)$ and $0.5\left(708-1135 \mathrm{~m}^{3} \cdot \mathrm{s}^{-}\right.$

$\left.13^{1}\right)$. Based on the shape of the curve fitted to the test data $\left(y=4.67+0.019 \mathrm{x}^{-1}\right)$, we assumed

14 entrainment would continue decreasing at discharges $>1135 \mathrm{~m}^{3} \cdot \mathrm{s}^{-1}$; therefore, we used $\mathrm{P}_{\mathrm{r}}$

15 values of 0.3 at discharges of $1136-1699 \mathrm{~m}^{3} \cdot \mathrm{s}^{-1}$ and 0.2 at discharges $>1699 \mathrm{~m}^{3} \cdot \mathrm{s}^{-1}$.

16 We tested our assumptions about the effect of flow on expansion of tag detections and

17 subsequent estimates of migration timing by comparing the mean of median passage dates

18 between years when the mean monthly flow in November-April was $\leq 1135 \mathrm{~m}^{3} \cdot \mathrm{s}^{-1}$ (low-

19 average flow) and years when flow was $>1135 \mathrm{~m}^{3} \cdot \mathrm{s}^{-1}$ (high flow). We chose November-

20 April for our tests because these are the months of highest flow in the Willamette River. We

21 hypothesized that if our expansion factors underestimated detection of tagged fish at high

22 flows, then the estimated median date of passage in high flow years would shift from that in

23 low flow years; i.e., earlier median passage date for fish tagged as subyearlings because the

24 later part of their migration occurs in fall-winter, and later passage date for fish tagged in fall

25 because the early part of their migration occurs in fall-winter. We compared the mean of 
26 median dates of detection with $t$-tests between low and high flow years for fish tagged at

27 Leaburg Dam as fall migrants and for two groups of subyearlings: 1) spawning tributaries

28 (North and South Santiam and McKenzie rivers) and 2) the Willamette and Santiam rivers.

29 The means of the median dates of detection at Willamette Falls were not significant

30 between low-average and high flow years for fall migrants or subyearlings (Appendix Table

31 A-1), indicating our expansion factors were appropriate for estimating migration patterns at a

32 seasonal scale. We summarized bi-weekly detections of tagged fish at Willamette Falls to

33 estimate migration timing of juvenile salmon and each two-week period usually had some

34 days of low to average flows, which would have provided opportunities for higher detection

35 efficiency. 
37 Appendix Table A-1. Comparisons of passage timing at Willamette Falls between years when

38 November-April flow was low-average $\left(\leq 1135 \mathrm{~m}^{3} \cdot \mathrm{s}^{-1}\right)$ and years when flow was high

$39\left(>1135 \mathrm{~m}^{3} \cdot \mathrm{s}^{-1}\right)$ for tagged juvenile Chinook salmon released in three areas of the Willamette

40 River basin. Passage timing is mean of the median date of detection expressed as day of the

41 year starting January 1 of their first year of life.

\begin{tabular}{|c|c|c|c|c|c|c|}
\hline \multirow[b]{2}{*}{ River (migrant type) } & \multicolumn{2}{|c|}{ Low-average flow } & \multicolumn{2}{|c|}{ High flow } & \multirow[b]{2}{*}{$\mathrm{t}$} & \multirow[b]{2}{*}{$\mathrm{P}$} \\
\hline & Mean (n) & SD & Mean (n) & SD & & \\
\hline McKenzie at Leaburg Dam (fall migrants) & $425.7(3)$ & 6.4 & $428.2(8)$ & 27.3 & 0.16 & 0.44 \\
\hline North \& South Santiam, McKenzie (subyearling) & $233.8(11)$ & 73.6 & $239.6(8)$ & 72.4 & 0.17 & 0.43 \\
\hline Willamette and Santiam (subyearling) & $169.7(12)$ & 16.1 & $162.8(10)$ & 11.6 & 1.13 & 0.14 \\
\hline
\end{tabular}

42 